California Western School of Law

CWSL Scholarly Commons

Faculty Scholarship

2011

When Enough Is Not Enough: Correcting Market Inefficiencies In

The Purchase And Sale Of Residential Property Insurance

Kenneth S. Klein

California Western School of Law, kklein@cwsl.edu

Follow this and additional works at: https://scholarlycommons.law.cwsl.edu/fs

Part of the Insurance Law Commons

Recommended Citation

Kenneth S. Klein, When Enough Is Not Enough: Correcting Market Inefficiencies In The Purchase And Sale Of Residential Property Insurance,18 VA. J. SOC. POL'Y \& L. 345 (2011).

This Article is brought to you for free and open access by CWSL Scholarly Commons. It has been accepted for inclusion in Faculty Scholarship by an authorized administrator of CWSL Scholarly Commons. For more information, please contact alm@cwsl.edu. 


\section{HEINONLINE}

Citation: 18 Va. J. Soc. Pol'y \& L. 345 2010-2011

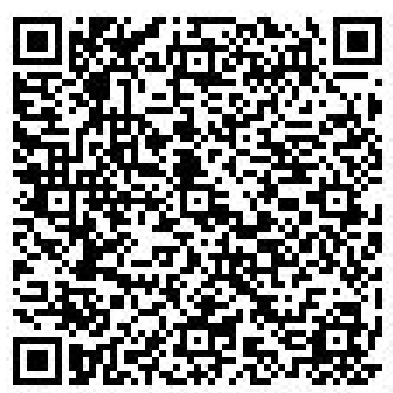

Content downloaded/printed from

HeinOnline (http://heinonline.org)

Fri Mar 28 13:36:50 2014

-- Your use of this HeinOnline PDF indicates your acceptance of HeinOnline's Terms and Conditions of the license agreement available at http://heinonline.org/HOL/License

-- The search text of this PDF is generated from uncorrected OCR text.

-- To obtain permission to use this article beyond the scope of your HeinOnline license, please use:

https://www.copyright.com/ccc/basicSearch.do?

\&operation $=$ go\&search $T y p e=0$

\&lastSearch $=$ simple\&all=on\&titleOrStdNo=1068-7955 


\title{
WHEN ENOUGH IS NOT ENOUGH: CORRECTING MARKET INEFFICIENCIES IN THE PURCHASE AND SALE OF RESIDENTIAL PROPERTY INSURANCE
}

\author{
By Kenneth S. Klein*
}

\begin{abstract}
Each year at least hundreds, and often thousands of Americans lose their homes to natural disasters striking populated areas. Tens of thousands lose their homes to single-instance fires, floods, or other catastrophes. The majority of these homeowners are underinsured, meaning they have less insurance than it will cost to rebuild their homes. This Article analyzes whether such underinsurance indicates correctible inefficiencies in the residential property insurance markets. The Article identifies two inefficiencies: (1) Inadequate information, which impairs informed pricing decisions by purchasers; and (2) Dispute costs (such as litigation) in the instances of loss exceeding coverage. The Article proposes addressing these inefficiencies by adopting a mandatory disclosure, provided at the time of purchase or renewal of insurance based on the EnergyGuide program labeling appliances for energy consumption, and in turn then barring litigation on adequacy of coverage.
\end{abstract}

\section{CONTENTS}

Abstract.

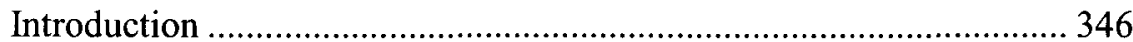

I. The Prevalence of Residential Underinsurance as a Result of Market Inefficiency ........................................................................ 350

A. The size of the residential property insurance market .................. 350

B. Theoretical incentives of homeowners and insurers when determining the amount of residential property coverage .......... 353

C. Regardless of economic modeling of optimal levels of insurance, homeowners actually want full insurance................... 358

1. The Pervasiveness of Underinsurance. ...................................... 358

2. The Pervasiveness of Unintended Underinsurance. .................. 360

\footnotetext{
* Associate Professor of Law, California Western School of Law. This Article was written with the support of a research stipend from California Western School of Law. As always, the Author extends thanks in the writing of this Article to his editor, colleague, and wife, Professor Lisa Black. The Author also appreciates the invaluable assistance and input of the staff of the CWSL Library; his research assistants, Jared Hestetune and Jihan Younis; his professional academic colleagues, Professors Mitch Crusto, Donald Smythe, Theodore Klastorin, and Ed Dauer; his attorney colleagues in the policyholder advocacy community, Amy Bach and Karen Reimus; and his brother who works in the insurance industry, Jonathan Klein. The Author additionally thanks the editorial staff of the Virginia Journal of Social Policy and the Law for its support and assistance - they have made this Article better.
} 
D. The pervasiveness of ambiguity concerning whether the insurer or the homeowner bears the risk of undervaluation resulting in underinsurance

E. One approach to eliminating insurer responsibility for undervaluation

F. The incentives to underinsure have created market inefficiencies 367

II. A History of Legislative and Judicial Responses to Information Inefficiencies in Insurance Transactions .......................................... 372

III. Legislative Proposal .............................................................. 376

A. Methods of Curing Information Inadequacy ................................ 376

B. A Proposal to Cure Information Inadequacy in Homeowner's

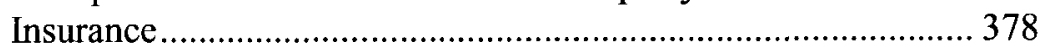

IV. The Case for The Proposal........................................................... 381

V. The Case against the Proposal (and a Response to It)....................... 382

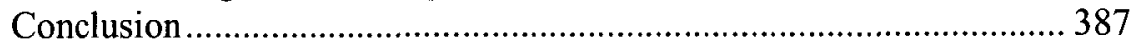

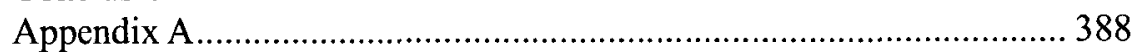

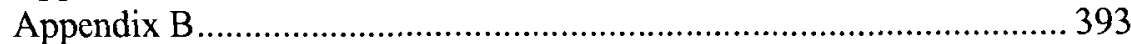

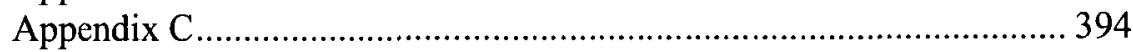

\section{INTRODUCTION}

Homeowners: if your home burned down tomorrow, would you have enough insurance to rebuild? In the wake of natural disasters, one recurring story is that a large number of Americans mistakenly answer "yes," when the correct answer should be "no." This Article analyzes whether this situation indicates correctable market inefficiencies. ${ }^{2}$ In the

1 See, e.g., Kelsey D. Dulin, The Disaster After the Disaster: Insurance Companies' Post-Catastrophe Claims Handling Practices, 61 OKLA. L. REV. 189 (2008); Kathy Chu \& Elizabeth Weise, Wildfires Spotlight Insurance Coverage Issues, USA TODAY, Nov. 2, 2007, at B1; Joseph B. Treaster, Homeowners Come Up Short On Insurance, N.Y. TIMES, Aug. 31, 2004, at A1; David Lazarus, Underinsured Wildfire Victims Feel Burned Again When Coverage Comes Up Short, L.A. TIMES, Nov. 19, 2008, at C1; CBS Evening News: Underinsurance with Allstate (CBS television broadcast July 14, 2008) (t ranscript available at http://www.cbsnews.com/stories/2008/07/14/eveningnews/ main4261407.shtml) (last visited June 22, 2009) [hereinafter CBS Evening News]; Liz Pulliam Weston, The Basics: Why 2 Out of 3 Homes Are Underinsur ed, MSN MONEY, Apr. 21, 2004, http://moneycentral.msn.com/content/Insuranc e/Insureyourhome/P35340.asphttp://moneycentral.msn.com/content/Insurance/I nsureyourhome/P35340.asphttp://moneycentral.msn.com/content/Insurance/Insu reyourhome/P35340.asp (last visited June 23, 2009); Cynthia Beisiegel, Underinsured Homeowner Problem Revisited on Anniversary of California Wildfires, INS. J., Nov. 8, 2004, at 21; Elliot Spagat, Homeowners Haunted by Underinsurance, CONTRA COSTA TIMES, July 11, 2004, http://www.ufaa.com/N ews Articles/haunted.htm.

${ }^{2}$ Economics does not use the jargon of a working or failing market, but rather classifies markets as efficient or inefficient. Inefficient markets are ones unnecessarily burdened with external costs or risks, such as a cost or risk that 
wake of natural disasters in populated areas, insurance companies can incur billions of dollars of exposure on property claims, ${ }^{3}$ and homeowners can incur hundreds of millions of dollars of uninsured losses. ${ }^{4}$ Hurricane Katrina alone resulted in roughly 18 billion dollars of insured losses. ${ }^{5}$ Across the United States in the single year of 2007 , 41,000 homeowners lost their homes to disaster. ${ }^{6}$ That same year the average home was worth roughly $\$ 191,500,^{7}$ and about $40 \%$ of those homes were underinsured by an average of about $20 \%{ }^{8}$ If all 41,000 homes lost to disaster were insured, then even assuming the cost to rebuild is the same--and not more than the appraised market value of a home, a more realistic assumption- $\$ 628,120,000$ in uncovered disaster losses to insured homes occurred in a single year. The October and November 2007 Southern California firestorms alone resulted in 1732

could be eliminated with a solution costing less than the cost or risk itself, or a transactional cost or risk allocated to a party inadequately apprised of the allocation and thus without a reasonable opportunity to account for the cost or risk when negotiating the transaction price. See, e.g., Inefficient Market Definition, THE FREE DICTIONARY, http://financial-dictionary.thefreedictionary. com/Inefficient+Market ("A market where prices do not always reflect available information as accurately as possible. Inefficient markets may result from a lag in information transferring to one place to another, deliberate withholding of information by an insider, or other reasons."); accord Freeman v. Laventhal \& Horwath, 915 F.2d 193, 198 (6th Cir. 1990) ("An inefficient market, by definition, does not incorporate into its price all the available information about the value of a security.") (citing Lipton v. Documation, Inc., 734 F.2d 740, 746 (1 1 th Cir. 1984); Reingold v. Deloitte Haskins \& Sells, 599 F. Supp. 1241, 1264 (S.D.N.Y. 1984)).

${ }^{3}$ See, e.g., Howard Kunreuther, Linking Insurance and Mitigation to Manage Natural Disaster Risk, printed in GEORGES DIONNE, HANDBOOK OF INSURANCE 593-618 (Kluwer 2000); see also Kathy Bushouse, What Wrecked Property Insurance?, S. FLA. SUN-SENTINEL, Jan. 14, 2007, http://insurancenewsnet.com/ article.aspx? $\mathrm{a}=$ top_pc\&id=74304 ("the 2004 and 2005 hurricane seasons that caused $\$ 35.9$ billion in insured losses"); Insurance Services Office, ISO'S PPC Program, at 1 (2001) (fire is "the largest single cause of property loss in the United States," causing "direct losses of more than $\$ 120$ billion and countless billions more in related costs").

${ }^{4}$ See Chu \& Weise, supra note 1; Lazarus, supra note 1; Treaster, supra note 1; CBS Evening News, supra note 1; CAL. DEP'T OF INS., ESTIMATE OF SUMMARY LOSS DATA RESUlTING FROM THE NOVEMBER 2008 SOUTHERN CALIFORNIA FIRES, Data as of May 10, 2009.

${ }^{5}$ E-mail from Gary Kerney, Assistant Vice President of Property Claims Servs., Insurance Services Office, to Jihan Younis (June 16, 2009) (on file with author).

${ }^{6}$ U.S. Census Bureau, AmeriCAN Housing Survey for the United States: 2007, tbl.3-11 [hereinafter 2007 HOUSING SURVEY tbl.3-11].

${ }^{7}$ U.S. CENSUS BUREAU, AMERICAN HOUSING SURVEY FOR THE UNITED STATES: 2007, tbl.1 A-7 [hereinafter 2007 HOUSING SURVEY tbl.1 A-7].

${ }^{8}$ Peter M. Wells, Insuring to Value: Meeting a Critical Need 46 ( $2 \mathrm{~d}$ ed. 2007). 
total loss residential claims. ${ }^{9}$ A six-month after-the-fact survey of the subset of homeowners who lost their homes to the October 2007 wildfires in San Diego reported the average amount of underinsurance at $\$ 240,0000^{10}$

Based on data such as this, the media assumes and asserts that the insurance market is somehow "broken" -- a colloquial, intuitive conclusion that the expected market mechanisms have failed in an unspecified manner. " But an efficient transaction occurs when a rational, adequately informed ${ }^{12}$ buyer and seller agree to a particular level of insurance coverage at a particular price, in an arms-length negotiation, even without regard to later financial consequences for one party or the

${ }^{9}$ CAL. Dep'T Of InS., Estimate of Summary Loss Data Resulting from the OCTOBER AND NOVEMBER 2007 SOUTHERN CALIFORNIA FIRES, Data as of December 20,2008. This surely resulted in some homeowners never being able to rebuild. For insurers, the likely consequences are less severe. Insurance Services Office, Managing Catastrophe Risk, May 1996, at 4 ("Large catastrophes are rare; therefore, an insurer that does not have high catastrophe limits is likely to survive."). Perhaps in recognition of the disparate impact of underinsurance on homeowners and insurers, industry spokespersons may minimize the frequency of underinsurance. Lazarus, supra note 1 ("It happens, but it doesn't happen as often as you might see in the media.").

${ }^{10}$ UNITED POLICYHOLDERS, http://www.uphelp.org/library/resource/southerncalifornia-wildfire-claim-survey-results (last visited Apr. 14, 2011). The complete data set is on file with the author. Obviously, the value of these homes was substantially above the national average.

${ }^{11}$ See, e.g., Bushouse, supra note 3 ("legislators prepare to plunge into debate on the best ways to repair the broken insurance market"). During the debate in 2009 and 2010 over comprehensive health care reform, politicians and commentators also adopted the jargon of a "broken insurance market" to convey the concept of perceived complex structural market failures. See, e.g., Letter from Health Care for America Now to Christine Varney, Assistant Attorney Gen., U.S. Dep't of Justice (May 19, 2009) available at http://hcfan.3cdn.net/60de4bc8c6929815dc_urm6bhu9z.pdf ("HCAN believes that it would be a mistake to rely solely on this broken insurance market to generate increased value in our health care system."); David Dayen, Obama Administration Trying to Stop Degrading of Employer-Based Healthcare, FIREDOG LAKE (June 14, 2010, 1:21 PM), http://news.firedoglake.com/2010/06/ 14/obama-administration-trying-to-stop-degrading-of-employer-based-healthcare (" $[\mathrm{C}]$ osts for employers, among the more stable in the broken insurance market, are expected to jump $9 \%$ in 2011 ..."); Tevi Troy, A Fixed Insurance Market Is Still a Broken Insurance Market, NAT'L REV. ONLINE, Feb. 22, 2010, http://www.nationalreview.com/critical-condition/47584/fixed-insurancemarket-still-broken-insurance-market/tevi-troy.

${ }^{12}$ The terminology "adequately informed" recognizes that the law may impose a limitation or allocation of risk through contractual disclosures that are not "full" or "perfect." See generally Mark Geistfeld, The Political Economy of Neocontractual Proposals for Products Liability Reform, 72 TEX. L. REV. 803 (1994). 
other. ${ }^{13}$ "Underinsurance"-instances when the amount of coverage is less than the insurable value of the home-does not, in and of itself, indicate market inefficiency; for example, a rational homeowner who has adequate information concerning home value and the cost of insurance and who has a very remote likelihood of a significant loss might intentionally and efficiently purchase less than full insurance.

This Article will step away from the ex post facto accusations and pejorative characterizations surrounding insurance and underinsurance in the wake of mass loss, and analyze the market for actual inefficiencies susceptible to reform. ${ }^{14}$ This Article concludes that the structure of residential insurance markets gives an incentive to undervalue the cost of rebuilding a home, and that insurance policies mask both the possibility of undervaluation and the allocation between homeowner and insurer of the risk of undervaluation. Simply put, many homeowners do not know how much it would cost to rebuild their homes, do not know that they are underinsuring their homes, and do not know that if they lose their homes, courts may say that their lack of insurance is their own fault. The result is confusion in the pricing of coverage, and litigation in the event of loss. These are, broadly speaking, market inefficiencies resulting from inadequacy of information.

In seeking to address these inefficiencies, this Article builds on the work of Professors Daniel Schwarcz and Jeffrey Stempel, who argue that insurance may be more properly thought of as a product, rather than a contract. ${ }^{15}$ This Article applies that approach to residential property insurance as a means to address the heretofore seemingly intractable problem of adequate information disclosures in determining the insured value of a home. ${ }^{16}$

${ }^{13}$ See Burkhardt v. Bailey, 680 N.W.2d 453, 464 (Mich. Ct. App. 2004) ("“[T]he bedrock principle of American contract law [is] that parties are free to contract as they see fit, and the courts are to enforce the agreement as written absent some highly unusual circumstance, such as a contract in violation of law or public policy." (quoting Wilkie v. Auto-Owners Ins. Co., 469 Mich. 41, 51 (2003)).

${ }^{14}$ This Article will not address the related topic of how to address intentional or negligent misconduct by agents or brokers.

${ }^{15}$ See Daniel Schwarcz, A Products Liability Theory for the Judicial Regulation of Insurance Policies, 48 WM. \& MARY L. REV. 1389 (2007); Jeffrey W. Stempel, The Insurance Policy as Thing, 44 TORT TRIAL \& INS. PRAC. L.J. 813 (2009).

${ }^{16}$ This Article comes with a caveat. Of necessity, this Article touches upon issues of highly theoretical economics. The Author is not an economist, and is ill-suited to evaluate the highly sophisticated theorems of insurance pricing, behavior, and market structure developed in nuanced economic models. See, e.g., GEORGES DIONNE, HANDBOOK OF INSURANCE (Kluwer 2000). Rather, this Article seeks to provide the platform for sensible legal regulatory reform of the 
Section I of this Article broadly describes the market structure of the purchase and sale of residential property insurance, reviewing the theoretical incentives for both buyers and sellers either to fully insure or to underinsure, and identifies two inefficiencies in the conveyance of adequate information-both concerning the adequacy of coverage. Section II briefly surveys the historical and extant regulatory and judicial responses to adequacy of coverage disputes. Section III proposes a regulatory reform of the insurance markets. Section IV makes the case for the proposal of Section III. Section V addresses anticipated criticisms of the proposal of Section III.

\section{The PreVAlEnCE of Residential Underinsurance as a ReSUlt OF MARKET INEFFICIENCY}

\section{A. THE SIZE OF THE RESIDENTIAL PROPERTY INSURANCE MARKET}

The residential property insurance market has over $50,000,000$ captive customers, each of whom on average must have at least $\$ 100,000$ of residential property insurance. This is because anyone who has a mortgage must have mortgage insurance of at least the amount of the outstanding principal of the mortgage. Of course, people also may voluntarily insure, and may insure for more than their mortgage balance. Measured by annual premiums, the residential property insurance market is a multi-billion dollar market.

In 2007, there were $75,647,000$ owner-occupied homes in the United States. ${ }^{17}$ Of these homes, $48,742,000$ had a regular and/or home equity mortgage. ${ }^{18}$ Indeed, 12,588,000 owner-occupied homes had two or more

residential property insurance markets, based on observable market behavior. This Article indeed often relies on the words of insurers and homeowners themselves in describing their decisions and perceptions.

172007 HOUSING SURVEY tbl.1A-7, supra note 7. This Article uses 2007 data because it is the closest year from which there is comparative data from other sources relied upon in this Article. See infra notes 62-63 and accompanying text. In other words, 2007 is the best year to use to stay as best one can within an "apples to apples" approach. There is, however, now a 2009 American Housing Survey, and its data is reported in the footnotes of this Article. The 2009 American Housing Survey reflects that between 2007 and 2009 there is stability in the numbers. For example, in 2009, there were $76,428,000$ owner occupied homes in the United States, an increase of just one percent over 2007. U.S. Census Bureau, American Housing Survey for the United States: 2009, tbl.3-1 [hereinafter 2009 HOUSING SURVEY tbl.3-1].

18 U.S. Census Bureau, American Housing Survey for the United STATES: 2007, tbl.3-15 [hereinafter 2007 HOUSING SURVEY tbl.3-15]. In 2009, $50,300,000$ homes had a regular and/or home equity mortgage. U.S. CENSUS BUREAU, AMERICAN HOUSING SURVEY FOR THE UNITED STATES: 2009, tbl.3-15 [hereinafter 2009 Housing SURVEY tbl.3-15]. 
mortgages. ${ }^{19}$ In 2007, 24,631,000 owner-occupied homes included the cost of property insurance as part of their primary mortgage payment. ${ }^{20}$ (Almost certainly, in the majority of these instances, this occurred because the homeowner had insufficient initial equity, and so a condition of the loan was the creation of monthly payment-funded escrows for insurance premiums, taxes, and so-called purchase-money insurance.)

Because of the structure of the secondary markets in mortgages, having a mortgage equates to having homeowner's insurance. ${ }^{21}$ The standard covenants for mortgages can be found on the websites of Fannie Mae and Freddie Mac. ${ }^{22}$ Each exemplar includes the requirement that a mortgagee maintain hazard insurance on a home "in the amounts (including deductible levels) and for the periods that Lender requires.",23

As a consequence, the insurance industry has a captive market of at least 50,000,000 customers. In 2007, at least 48,742,000 homes were required to have insurance by the explicit terms of mortgage. By 2009 , the figure was $50,300,000$. The duty of a mortgagee to have insurance can also exist independently of the explicit terms of the mortgage. ${ }^{24}$ And,

192007 HOUSING SURVEY tbl.3-15, supra note 18. In 2009, 11,697,000 owner occupied homes reported having two or more mortgages. 2009 Housing SURVEY tbl.3-15, supra note 18.

${ }^{20} 2007$ HOUSING SURVEY tbl.3-15, supra note 18. In 2009, 26,595,000 owneroccupied homes included the cost of property insurance as part of their primary mortgage payment. 2009 HOUSING SURVEY tbl.3-15, supra note 18.

21 In 1970, Congress created the Federal National Mortgage Association (FNMA, which today is popularly nicknamed Fannie Mae) and the Federal Home Loan Mortgage Corporation (FHLMC, which today is popularly nicknamed Freddie Mac). Emergency Home Finance Act of 1970, 12 U.S.C. $\S \S$ 1713,1717 (1970). The purpose of these entities was to "establish a secondary market for conventional mortgages, primarily single family homes." Raymond A. Jensen, Mortgage Standardization: History of Interaction of Economics, Consumerism and Governmental Pressure, 7 REAL PROP. PROB. \& TR. J. 397, 399 (1972). "[T]he policy decision was made by the two corporations that the first order of business must be the development of a standard mortgage form." Id.

${ }^{22}$ FANNIE MAE, http://www.efanniemae.com; FrEDDIE MAC, http://www.freddi emac.com (last visited Apr. 14, 2011).

${ }^{23}$ See, e.g., FANNIE MAE, California Security Instrument Form 3005: Word, at 6, available at https://www.efanniemae.com/sf/formsdocs/documents/secinstru ments/doc/3005w.doc; FANNIE MAE, New York Security Instrument Form 3033: Word, at 7, available at https://www.efanniemae.com/sf/formsdocs/documents/s ecinstruments/doc/3033. The full text of the relevant covenant from each of these documents is reproduced in Appendix A hereto. See WELLS, supra note 8, at 11 .

${ }^{24}$ See Raymond R. Koenders, Annotation, Duty of Mortgagee of Real Property With Respect to Obtaining or Maintenance of Fire or Other Casualty Insurance Protecting Mortgagor, 42 A.L.R.4th 188 (1985 and 2009 Supp.). 
of course, a homeowner may opt to purchase home insurance without a legal or contractual requirement to do so.

Most residential insurance has a stated cap, or limit, on the proceeds available to respond to a total loss. Put another way, residential property insurance usually is not a "guaranteed replacement" policy (a policy that pays for the rebuilding of a home regardless of cost). ${ }^{25}$

If an insurance policy is not "guaranteed replacement," the amount of coverage may be but is not necessarily "full," meaning that the coverage amount will equal the entire approximated cost of rebuilding the home. Even for a mortgaged home with mandated insurance, the insurance purchase transaction will involve some latitude about the percentage of coverage relative to the cost to rebuild the insured home in the instance of total loss. While residential insurance protects the largest asset most consumers will ever own, ${ }^{26}$ a mortgage does not require the homeowner to fully insure, but rather requires the mortgagee to insure up to the outstanding principal of the loan. ${ }^{27}$

The outstanding principal of the mortgage(s) on a home typically is less than the value of the home. In 2007, the national median value of an owner-occupied home was $\$ 191,471 .^{28}$ In 2007 , the median outstanding principal on mortgages of owner-occupied homes was $\$ 100,904 .{ }^{29}$ Even in the heart of the 2009-2010 "sub-prime mortgage crisis," analysts

${ }^{25}$ See Insurance Services Office, The Impact of Catastrophes on Property Insurance, at 3 (Jan. 1994); WELLS, supra note 8, at 21; see also Treaster, supra note 1; Weston, supra note 1; Liz Pulliam Weston, Flirting With Disaster: Millions of People Are Now Exposed to The Possibility of a Devastating Loss, L.A. TIMES, Aug. 2, 1998, at D; Rome Neal, Millions of Homes Under-Insured, CBS NEwS, Sept. 15, 2004, http://www.cbsnews.com/stories/2004/09/14/earlysh ow/contributors/raymartin/main643465.shtml (last visited June 24, 2009); Daniel Schorn, Is Your Home Underinsured?, CBS NEws, July 4, 2007, http://w ww.cbsnews.com/stories/2007/07/04/business/realestate/main3015665_page2.sh tml (last visited June 25, 2009).

${ }^{26}$ CAL. DeP'T OF INS., STAT. ANAlysis Div., Homeowners Study, at 2 (2008) (reproduced at http://www.insurance.ca.gov/0400-news/0200-studies-reports/02 50-homeowners-study).

${ }^{27}$ See Koenders, supra note 24.

${ }^{28} 2007$ HOUSING SURVEY tbl.1A-7, supra note 7. The separately published information of the U.S. Census Bureau puts the figure slightly higher, at $\$ 194,300$. U.S. Census BurEaU, AMERICAN COMMUNITY SURVEY: 2007, tbl.961, available at http://www.census.gov/compendia/statab/2010/tables/10s09 61.pdf. In a stark reflection of the bursting of the housing bubble, the median value for 2009 dropped to $\$ 170,000$. U.S. CENSUS BUREAU, AMERICAN HOUSING SURVEY FOR THE UNITED STATES: 2009, tbl.3-14 (2010) [hereinafter 2009 HOUSING SURVEY tbl.3-14].

${ }^{29} 2007$ HOUSING SURVEY tbl.1A-7, supra note 7. For 2009, the figure was $\$ 106,909.2009$ Housing SURVEY tbl.3-15, supra note 18. 
calculated that roughly $75 \%$ of homes had value exceeding the outstanding principal of any loans or mortgages against the property. ${ }^{30}$ The National Association of Insurance Commissioners calculates that in 2006, "Dwelling Fire and Homeowners Owner-Occupied" insurance policies covered over 60 million homes and accounted for over $\$ 48$ billion in premiums. ${ }^{31}$

\section{B. THEORETICAL INCENTIVES OF HOMEOWNERS AND INSURERS WHEN DETERMINING THE AMOUNT OF RESIDENTIAL PROPERTY COVERAGE}

Many economists theorize that given the flexibility to determine the amount of coverage, the "optimal" choice by a homeowner may be less than full coverage. ${ }^{32}$ Since the likelihood of a total loss is so remote, they say, purchasing a full indemnity for this risk produces very low marginal utility. ${ }^{33}$ This economic idea is in harmony with other studies showing that the more remote a risk is, the less likely a consumer will voluntarily insure against it. ${ }^{34}$

The likelihood in any given year of losing a home to disaster is, in fact, very remote: the 2007 American Housing Survey data reports that

${ }^{30}$ Underwater Mortgages on the Rise According to First American CoreLogic Q4 2009 Negative Equity Data, FIRST AMERICAN CORELoGIC, Feb. 23, 2010, at 1, http://www.loanperformance.com/infocenter/library/Q4_2009_Negative_Equi ty_Final.pdf.

31 - NAT'L ASS'N OF INS. COMm'RS, 2006 DWElling Fire, HomeOWNers OWNER-OCCUPIED AND HOMEOWNERS TENANT AND CONDOMINIUM/COOPERAT IVE UNIT OWNER'S INSURANCE REPORT, at 34 tbl.4, http://www.naic.org/docum ents/research_stats_homeowners_sample.pdf.

${ }^{32}$ See generally $\bar{V}$ ernon L. Smith, Optimal Insurance Coverage, 76 J. POL. ECON. 68 (1968); George G. Szpiro, Optimal Insurance Coverage, 52 J. RISK \& INS. 704 (1985). But see Christian Gollier, Optimal Insurance Design: What Can We Do With and Without Expected Utility?, printed in GEORGES DIONNE, HANDBOOK OF INSURANCE 97-115 (Kluwer 2000) (arguing that if information is adequate and symmetrical, the optimal insurance for a risk adverse purchaser may be full insurance, depending upon various factors, such as the type of deductible). An instructive analysis of the complexity of modeling optimal insurance coverage (even assuming symmetrical information) is found in Harris Schlesinger, The Theory of Insurance Demand, printed in GEORGES DIONNE, HANDBOOK OF INSURANCE 131-51 (Kluwer 2000).

${ }^{33} \mathrm{Id}$.

${ }^{34}$ Daniel Schwarcz, A Products Liability Theory for the Judicial Regulation of Insurance Policies, 48 WM. \& MARY L. REV. 1389, 1420-21 (2007) (citing, among other sources, RISA PALM, EARTHQUAKE INSURANCE: A LONGITUDINAL Study OF CAlifornia Homeowners 5-6 (1995); Paul Slovic ET AL., Preference for Insuring Against Probable Small Losses: Insurance Implications, in THE PERCEPTION OF RISK 51, 67-68 (Paul Slovic ed., 2000)); HowARD Kunreuther, Disaster Insurance Protection: Public Policy Lessons 236-37 (1978). 
of the 75,647,000 owner-occupied homes in the United States, ${ }^{35} 41,000$ homeowners of owner-occupied units (roughly one-twentieth of one percent) reported that they moved from their home because of a "Disaster loss (fire, flood, etc.).",36

An insurer has at least three incentives to write less than full coverage. The first is the concern of moral hazard. Economists who study insurance posit that in theory, less than full coverage reduces the incidence of loss by exposing the insured to some personal financial risk from a loss. ${ }^{37}$ There is little literature to support the conclusion that moral hazard normatively results in behavior that causes the loss of homes (it seems counterintuitive that a person is more likely to engage in risky behavior, such as smoking in bed, simply because he has full insurance; indeed, intuitively it seems just as likely that the person willing to take the risk of smoking in bed is also more likely to gamble on having less insurance), but reality does not matter-insurers perceive moral hazard as a real concern ${ }^{38}$ and based on this perception have an incentive to write less than full coverage.

A second concern of insurers is adverse selection. Adverse selection is premised on the notion that because high-risk insureds will never voluntarily self-identify their risk behaviors to an insurer, there is an asymmetry of information between insured and insurer concerning risk. Insurers therefore would have to overcharge premiums to all customers (to such a level that insurance would fail as a product) unless the insurer has the freedom to broadly categorize customers and price risk based upon the more generic characteristics of the customer. ${ }^{39}$ This strategy can run afoul of other legal and societal interests (hence the pejorative characterization of adverse selection as "redlining"), and thus is not an

${ }^{35} 2007$ HOUSING SURVEY tbl.1 A-7, supra note 7.

${ }^{36} 2007$ HOUSING SURVEY tbl.3-11, supra note 6. In 2009 , of the $76,428,000$ owner occupied homes, 24,000 (or three-hundredths of one percent) home owners reported that they moved from their home because of a "Disaster loss (fire, flood, etc.)." 2009 HousING SURVEY tbl.3-1, supra note 17; U.S. CENSUS BUREAU, AMERICAN HOUSING SURVEY FOR THE UNITED STATES: 2009, tbl.3-11. ${ }^{37}$ Steven Shavell, On Moral Hazard and Insurance, 79 Q.J. ECON. 541 (1979). See also Ralph A. Winter, Optimal Insurance under Moral Hazard, printed in GEORGES DiONNE, HANDBOOK OF INSURANCE 155-83 (Kluwer 2000); Mark V. Pauly, Overinsurance and Public Provision of Insurance: The Roles of Moral Hazard and Adverse Selection, 88 Q.J. ECON. 44, 45 (1974) (“[A]n optimal solution in this kind of 'moral hazard' situation is for the insured to retain some part of his losses."). While I will argue at the end of this Article that moral hazard imposes no cost on insurers, what matters at this juncture is that, as these sources confirm, insurers consider moral hazard in analyzing optimal coverage. ${ }^{38} I d$.

${ }^{39}$ See generally Georges Dionne, Neil Doherty \& Nathalie Fombaron, Adverse Selection in Insurance Markets (Working Paper 00-05, 2000), available at http://neumann.hes.ca/gestiondesrisques/00-05.pdf. 
unfettered strategy option for insurers. ${ }^{40}$ Constricting the ability to use adverse selection creates an incentive to adopt an alternative strategy: write less than full insurance for all customers.

The third incentive involves capturing and retaining market share. The customer decision when purchasing new insurance can be a nuanced one. ${ }^{41}$ But the purchase of residential property insurance is materially price elastic. ${ }^{42}$ Residential property insurance is largely a commoditized product. ${ }^{43}$ Sellers (insurers) compete on price. Put another way, while the public may allege that its decision-making is based on other factors, ${ }^{44}$ insurers understand that the buying decision often is made on the basis of premium. Thus, if the seller (the insurer) perceives that the costs of selling full insurance outweigh the benefits, it has an incentive to suppress price (the insurance premium) by selling less than full insurance.

The industry perceives the cost consequence of selling full insurance to be high. A 1996 whitepaper by the Insurance Services Office, a selfdescribed "leading industry source of information about risk," 45 found that "[a]n insurer willing to pay the price of sufficient catastrophe insurance could have trouble competing for business. ${ }^{46}$

40 See generally Gregory D. Squires, Racial Profiling, Insurance Style: Insurance Redlining and the Uneven Development of Metropolitan Areas, $25 \mathrm{~J}$. URB. AFF. 391 (2003).

${ }^{41}$ An extended discussion of how and why customers choose their insurers is found in Schwarcz, supra note 34, at 1404-22.

${ }^{42}$ Economic research describes that residential property insurance is more price elastic than other types of insurance, and catastrophe insurance is even more so. See generally Martin F. Grace, Robert W. Klein \& Paul R. Kleindorfer, Homeowners Insurance with Bundled Catastrophe Coverage, 71 J. RISK \& INS. 351 (2004).

${ }^{43}$ One indicium that residential property insurance is a commodity is that there are only six variations of policies, and $80 \%$ of all policies are written on an identical form. 2006 Dwelling Fire, Homeowners Owner-Occupied, and Homeowners Tenant and Condominium/Cooperative Unit Owner's Insurance Report, NAT'L ASS'N OF INS. COMM'RS 34 tbl.4, http://www.naic.org/document s/research_stats_homeowners_sample.pdf. But see Daniel Schwarcz, The Need for Insurance Policy Transparency, 77 U. CHI. L. REv. (forthcoming Dec. 2011) (arguing that some coverage differs "radically" amongst insurers).

${ }_{44}$ See Jeffrey E. Thomas, An Interdisciplinary Critique of the Reasonable Expectations Doctrine, 5 CONN. INS. L.J. 295, 311 (1998) (citing data that reputation is the primary driver of consumer choice of homeowner insurer).

${ }_{45}$ About ISO, INSURANCE SERVICES OFFICE, http://www.iso.com/AboutISO/Overview/About-ISO.html (last visited April 1, 2011).

${ }^{46}$ Insurance Services Office, Managing Catastrophe Risk (1996), at 4; accord WELLS, supra note 8 ("As the industry moved closer to capped policy limits, making certain that the policy limits included all of the costs faced when losses 
Conversely, the perceived consequence of selling less than full insurance is very small. Very rarely will a homeowner have a loss that exceeds coverage (and thus potentially results in ex post facto customer dissatisfaction), even if the customer has less than full insurance. It is reported that less than $2 \%$ of residential insurance claims are for the total loss of a house, ${ }^{47}$ and American Housing Survey data suggests it is far less than $2 \%{ }^{48}$ Put another way, if in any given year an insurance claim in any amount is remote, and total loss claims are exceptionally rare, and at least some of those claims will have adequate insurance ${ }^{49}$. The likelihood of an underinsured total loss claim is, in a word, negligible. Now contrast that "likelihood," such as it is, with the counter-incentive that, "gaining greater market share ... build[s] an increased capital base for investment." perceive that selling less than full insurance in order to capture greater market share puts their business at risk of survival: "Large catastrophes are rare; therefore, an insurer that does not have high catastrophe limits is likely to survive."

Of even greater potential importance are the incentives that arise in retaining existing customers. The 2009 American Housing Survey reports that of the $76,428,000$ total owner occupied homes in 2009 , $19,482,000$ were acquired in the five years $2005-2009 .{ }^{52}$ In other words, five percent $(19,482,000 / 5 / 76,428,000)$ of homes change hands in a year, which is the event that (if it is a mortgaged home) precipitates new insurance of necessity. If, in any given year, there are not a lot of new insurance customers, this puts a premium on retaining existing customers. In the early 1990s, one insurer, Allstate, calculated its

occurred [would charge] ... premiums [increased] commensurate with the entire risk assumed."). Again, it does not matter whether insurers are correct in this evaluation; what matters is that insurers perceive that the insurer cannot afford to write full insurance. This perception is a strong incentive to not write full insurance.

${ }^{47}$ Treaster, supra note 1; Neal, supra note 25 . While reliance on media reports for this figure is less than ideal, the insurance industry does not routinely publicly disseminate its industry data.

${ }^{48}$ See 2007 Housing SURVEY tbl.1 A-7, supra note 7; 2007 Housing SurveY tbl.3-11, supra note 6 .

${ }^{49}$ This is, of course, why residential property insurance is relatively inexpensive.

${ }^{50}$ WeLLS, supra note 8 , at 50 .

51 Insurance Services Office, supra note 46, at 4; see also VERONIQUE Bruggeman, Compensating Catastrophe Victims: A comparative Law AND ECONOMICS APPROACH 96 (2010) ("[A] lot of factors can make it difficult for the insurance industry to supply liability insurance for man-made catastrophes, but there generally does not seem to be limited insurance capacity . ... [T] The U.S. insurance industry could adequately fund catastrophic property losses....").

${ }^{52}$ See 2009 Housing SURVEY tbl.3-14, supra note 28; 2009 HousING SURVEY tbl.3-15, supra note 18 . 
renewal rate of homeowners insurance at roughly $90 \%{ }^{53}$ Thus, the goal from the perspective of the insurer should be for the renewal to be as seamless as possible for the insured. In other words, the insurer should avoid prompting the customer to ponder whether there is an alternative, preferred insurer. In the frequently occurring environment of rising rebuilding costs, maintaining full coverage (or, for that matter, any percentage level of coverage) might militate a recurring revaluation of the property as well as increased premium. But this is contrary to the goal of seamless renewal. And since total loss claims appear to be extremely rare, the rational choice for the insurer is simply to let the coverage-to-value ratio deteriorate over time rather than raise premiums and thus lose an indeterminate set of renewals. This will cause even initially fully insured homeowners to become underinsured over time.

Indeed, not only does an insurer have incentive to sell less than full insurance, but also the insurer's agent or broker has incentive to understate the value ${ }^{54}$ of the home (the base figure against which percentage of coverage is calculated). ${ }^{55}$ In the period when most insurers wrote guaranteed replacement coverage, "[s]ales and marketing channels within insurance organization[s] would, with regular frequency, downplay the necessity of properly reflecting the replacement cost value needed to properly insure homes. ${ }^{, 56}$ Using correct valuation approaches "could create a conflict in goals between the best interests of the carrier or underwriter insuring a property and those of an agent primarily charged with the generation of new business." 57

Capping coverage does not change these incentives. A higher coverage still equates to higher premiums, which exposes an insurer to losing a customer on the basis of price. ${ }^{58}$ The likelihood of a claim exceeding coverage remains de minimus. Therefore the rational choice is to understate value. Reinforcing this view is work in law and economics confirming the common-sense intuition that insurance purchasers often are systematically uninformed about insurance or inclined to decide

\footnotetext{
53 Allstate, Total Personal Lines Administrative Meeting (Feb. 13, 1995), http://www.allstatenewsroom.com/media/PDF/H000000001.pdf; accord Justin Sydnor, Abundant Aversion to Moderate Risk: Evidence From Homeowners Insurance, at 14 (Working Paper, 2006 ), http://faculty.weatherhead.case.edu/sy dnor/deductibles_old.pdf ("[R]oughly $12 \%$ of the sample consisted of customers who were new to the company in the sample year.").

${ }^{54}$ For purposes of this Article, "value" refers to the cost of rebuilding the home.

${ }_{55}^{55}$ This incentive is alluded to in Neal, supra note 25.

${ }^{56}$ WeLLS, supra note 8, at 51.

${ }^{57} \mathrm{Id}$.

${ }^{58}$ Weston, supra note 1; Lazarus, supra note 1; Treaster, supra note 1; Chu \& Weise, supra note 1; Neal, supra note 25.
} 
irrationally about coverage, and that in either circumstance insurers are incentivized to (and do) exploit that circumstance. ${ }^{59}$

In summary, in analyzing the structure and incentives in residential insurance markets, one would predict that most customers should not want to insure to full value, most insurers would not want to insure to full value, and most insurance agents and brokers would wish to understate actual value.

\section{REGARDLESS OF ECONOMIC MODELING OF OPTIMAL LEVELS OF INSURANCE, HOMEOWNERS ACTUALLY WANT FULL INSURANCE}

The analysis of the residential property insurance market predicts that most customers would not want to insure to full value, and most insurers would not want to insure to full value. Actual market behavior largely bears out these predictions, but also exposes an important divergence: a large and growing segment of consumers (now approaching a majority) will choose to fully insure, despite the theoretical work arguing that full insurance is rarely if ever optimal.

\section{The Pervasiveness of Underinsurance.}

Marshall \& Swift/Boeckh, the company that manufactures the software insurers commonly use to calculate adequate insurance coverage, is self-interested in promoting the use of accurate tools to measure value. Marshall \& Swift/Boeckh reports that for the years it studied, roughly $60 \%$ of American homeowners were underinsured by roughly $20-25 \%:^{60}$

${ }^{59}$ SCHWARCZ, supra note 34, at 1403 (citing Victor P. Goldberg, Institutional Change and the Quasi-invisible Hand, 17 J.L. \& ECON. 461, 485 (1974); Michael I. Meyerson, The Efficient Consumer Form Contract: Law and Economics Meet the Real World, 24 GA. L. REV. 583, 595 (1990); Oren Bar-Gill, Seduction by Plastic, 98 Nw. U. L. REV. 1373, 1376 (2004); Jon D. Hanson \& Douglas A. Kysar, Taking Behavioralism Seriously: The Problem of Market Manipulation, 74 N.Y.U. L. REV. 630 (1999); and Jon D. Hanson \& Douglas A. Kysar, Taking Behavioralism Seriously: Some Evidence of Market Manipulation, 112 HARV. L. REV. 1420 (1999)).

${ }^{60}$ WeLLS, supra note 8 , at 46 ; see also Weston, supra note 1; Treaster, supra note 1 ; Neal, supra note 25 ; Chu \& Weise, supra note 1. 


\begin{tabular}{|l|l|l|}
\hline YEAR & $\begin{array}{l}\text { PERCENT OF HOMES } \\
\text { UNDERINSURED }\end{array}$ & $\begin{array}{l}\text { AVERAGE DEGREE OF } \\
\text { UNDERINSURANCE }\end{array}$ \\
\hline $\begin{array}{l}2002 \text { and } \\
\text { prior }\end{array}$ & $73 \%$ & $35 \%$ \\
\hline 2003 & $64 \%$ & $27 \%$ \\
\hline 2004 & $61 \%$ & $25 \%$ \\
\hline 2005 & $59 \%$ & $22 \%$ \\
\hline 2006 & $58 \%$ & $21 \%$ \\
\hline
\end{tabular}

This work is supported by the work of United Policyholders, a leading consumer advocacy group concerned with the frequency and cause of underinsurance. United Policyholders surveyed homeowners impacted by the 2007 wildfires in San Diego six months, one year, and two years after the loss of their homes; these surveys put the frequency of underinsurance at $66-75 \%{ }^{61}$

The Marshall \& Swift/Boeckh data, a nationally comprehensive study, describes that even if the "optimal" choice by a homeowner is to underinsure, the percentage of homeowners who fully insure is just over $40 \%$ - and is rising. Put another way, a material and increasing percentage of homeowners are sufficiently risk adverse that they will and do purchase full coverage. ${ }^{62}$

Even this $40 \%$ is not the full set of cases where the amount of insurance purchased is not economically "optimal." There also will be

${ }^{61}$ A hyperlink to the entirety of the survey data is found at http://www.uphelp.or g/library/resource/southern-california-wildfire-claim-survey-results (last visited Apr. 14, 2011). The complete data set is on file with the author, who has access to it by virtue of his work with UPH in the wake of the 2007 and 2008 California wildfires. In the years 2003-2008, Southern California has had seriatim wildfires in residential communities. There is no ambiguity that insurance covers losses to wildfire. Therefore, the Southern California wildfires provide a unique data set to study the issues raised in this Article.

62 The goal of the proposal within this Article is not that insurers are forced to sell, and homeowners are forced to purchase, the "optimal" level of insurance. Rather, the goal of this Article is to create sufficient comfort that the homeowner was adequately informed of the coverage level, so that in the event of an underinsured loss, there need not be protracted debate over who bears responsibility for the rebuild costs in excess of coverage. 
cases where the purchase is less than full but still too high, and cases where the purchase is too low-both not optimal purchases. ${ }^{63}$

In sum, residential property insurance is a market with over $60,000,000$ customers, and it appears that a material percentage, perhaps $50 \%$ or more, of these customers are purchasing other than the "optimal" amount of insurance.

\section{The Pervasiveness of Unintended Underinsurance.}

If, despite homeowners' desire to over-insure, insurers have both an incentive to undervalue and to underinsure, then one would predict that homeowners are actually purchasing less insurance-both in gross dollars and as a percentage of actual value-than the homeowners are seeking to purchase. This would then mean, by extension, that the percentage of homeowners who actually fully insure is less than the percentage of consumers who wish to fully insure. If the percentage of homeowners who actually fully insure currently is just over $40 \%$ and is rising, this suggests that the percentage of consumers who wish to fully insure is at least $50 \%$. Because of concern with moral hazard and adverse selection, one predicts that an insurer still has an incentive to not offer full value coverage to these consumers. Also, one predicts insurers have an incentive to understate actual full value.

Market behavior bears out these predictions. According to the Insurance Information Network of California, the 2003 Southern California firestorms totally destroyed 3631 homes and the 2007 Southern California firestorms totally destroyed 2180 homes; the two firestorms combined resulted in over 1000 (roughly 20\%) formal "Requests for Assistance"64 (RFA) to the California Department of Insurance regarding underinsurance (in other words, homeowners asserting they had less insurance than they had expected). The number of

${ }^{63}$ A consumer may unintentionally purchase too little coverage because of the insurer's incentive to understate the value of the insured structure. Thus, for example, if (1) the optimal level of insurance is $90 \%$ of value, (2) a homeowner intends to insure at $90 \%$ of value, (3) the home has an actual value of $\$ 400,000$, and (4) the insurer convinces the homeowner that the home value is $\$ 300,000$, then the homeowner will purchase $\$ 270,000$ of coverage, which is $\$ 90,000$ less than optimal coverage.

${ }^{64}$ An RFA is not a request for governmental financial assistance. Rather, it is the form that a consumer completes to initiate a formal investigation of an insurer's practices. See California Department of Insurance, About Us: An Introduction to CDI Operations (2004), http://www.insurance.ca.gov/0500-about-us/0100-cdiintroduction. 
requests increased in 2007 , despite a significantly fewer number of total home losses. ${ }^{65}$

Other data supports the conclusion that at least roughly $20 \%$ of homeowners had less insurance than they had expected. The work of United Policyholders reports that of homeowners of lost or damaged homes in the 2007 Southern California firestorms who had not reached an acceptable settlement with their insurer by six months after the fires, $17 \%$ reported filing an RFA with the Department of Insurance by one year after the fires. ${ }^{66}$ Two years after the fires, $28 \%$ had filed RFAs. ${ }^{67}$ But of the remaining $83 \%$, roughly one-third explained either a concern that it would make matters worse, they did not want to anger the insurer, they did not know how to file an RFA, or they did not think it would do any good. ${ }^{68}$ Six months after the fires, $74 \%$ of homeowners reported they did not have sufficient coverage to rebuild or repair their homes, and $64 \%$ of homeowners reported the amount of funds offered by their insurer was not sufficient to rebuild their homes (this included homeowners with partial losses).$^{69}$ Two years after the fires, $53 \%$ of homeowners reported they did ultimately have sufficient coverage to rebuild or repair their homes, while $47 \%$ reported the insurer agreed to pay them the full amount necessary to rebuild or repair their homes (this included homeowners with partial losses). ${ }^{70}$

${ }^{65}$ Insurance Information Network of California, Southern California Firestorms of $2003 \& 2007$ Compared (on file with author) (reproduced in full, infra app. $\mathrm{B}$ ). One of the many ways this could arise is when a homeowner meets with a broker or agent, answers all questions asked, and is quoted a policy price; that home owner would have little reason to be aware that the insurer may have used a "quick quote" function in the Marshall \& Swift software that calculates value incorrectly. See Weston, supra note 1; Treaster, supra note 1; Neal, supra note 25; Chu \& Weise, supra note 1.

${ }^{66}$ See one-year survey results data at http://www.uphelp.org/pdfs/OneYearSurve yResults2009.pdf.

${ }^{67} \mathrm{See}$ two-year survey results data at http://www.uphelp.org/survey_files/TwoY earSurveyResults.xls.

${ }^{68} I d$.

${ }^{69}$ See six-month survey results data at http://www.uphelp.org/survey_files/2007 WildfireClaimSurveyCompleteandPartialSurveyResults.htm. The apparent discrepancy between these two figures results from at least two scenarios: (1) instances when insurers offered settlements in excess of stated policy limits, and (2) instances when homeowners had insufficient coverage to rebuild precisely the home lost, but sufficient funds to rebuild a different home acceptable to them and the lender.

${ }^{70} \mathrm{See}$ two-year survey results data at http://unitedpolicyholders.org/survey/surve yresults.html. This later figure suggests that only a subset of the full group of underinsureds utilize a formal request for assistance (others in the group will do nothing, or will pursue less formal steps such as simply negotiating directly with the insurer, or will skip to more formal steps such as litigation). 
The ex post facto record of natural disasters is replete with anecdotal homeowner claims either that they wanted more insurance but could not get it, or that they were assured by their broker or agent that they had adequate insurance. ${ }^{71}$ But of course, what homeowners claim, especially after the fact, is hardly dispositive of what homeowners intended at the inception. The insurance industry itself, however, recognizes the pervasiveness of unintended underinsurance. One insurance trade journal reported from a 2010 Zogby/Metlife Auto \& Home insurance survey that "Nearly one third (31 percent) of Americans don't know how much their

${ }^{71}$ Chu \& Weise, supra note 1; Treaster, supra note 1; Lazarus, supra note 1; CBS Evening News, supra note 1; see also Free v. Republic Ins. Co., 8 Cal. App. 4th 1726, 1729 (Cal. Ct. App. 1992) ("According to the complaint ... [in 1979] and every succeeding year [until 1989] . . . appellant contacted [the insurance representative] to inquire whether the coverage limits if his policy were adequate to rebuild his home. On each occasion, he was informed they were."); Cheek v. State Farm Fire \& Cas. Co., 1997 U.S. App. LEXIS 5973 (9th Cir. Cal. Mar. 26, 1997) ('The Cheeks' Complaint alleged that State Farm was negligent in failing to provide them with a certain level of earthquake coverage, as they had specifically requested ... ."); Appellant's Opening Brief, Aslan v. State Farm Fire \& Cas. Co., 125 F.3d 857 (9th Cir. 1996), 1996 WL 33486909, at *5 ("Respondent assured Kenneth Asian [sic] that his earthquake policy was sufficient .... "); Desai v. Farmers Ins. Exchange, 47 Cal. App. 4th 1110, 1114 (Cal. Ct. App. 1996) ("Desai informed an insurance vendor, Carol Sacramone Insurance Agency, that he wanted 100 percent coverage . . . . Sacramone told Desai that Farmers Insurance Group offered the type of insurance Desai wanted, and orally represented that the policy provided ' $100 \%$ coverage' ...."); White v. Allstate Ins. Co., 513 F. Supp. 2d 674, 677 (E.D. La. 2007) ("Plaintiffs further allege that Tarleton indicated that the hurricane coverage under their homeowner's policy would cover any and all damages that might be incurred as a result of a hurricane."); Cameron Parish Sch. Bd. v. State Farm Fire \& Cas. Co., 560 F. Supp. 2d 485, 487 (W.D. La. 2008) ("In its Complaint, CPSB alleges that State Farm knew CPSB's flood insurance was insufficient, that State Farm knew CPSB wanted to maximize its flood insurance, and that State Farm did not tell CPSB additional flood insurance could be purchased outside of the NFIA and with another company."); Smith v. Kert LeBlanc Ins. Agency, Inc., 2008 U.S. Dist. LEXIS 43287, at *2-3 (E.D. La. 2008) ("Plaintiffs contend that they should be paid more than their policy limits because State Farm did not advise them upon renewal of their policy that the amount of their coverage would be insufficient to completely rebuild their home following its destruction . . . Plaintiffs argue that they specifically desired and purchased a "full replacement policy."'); Martinonis v. Utica Natl. Ins. Grp., 840 N.E.2d 994, 996 (Mass. App. Ct. 2006) ("“I definitely brought up to him all of this information and questioned him and asked him and asked him whether it shouldn't be increased. And he reassured me that that should be adequate."'); Stevens v. Hickey-Finn \& Co., Inc., 261 A.D.2d 300, 300-01 (N.Y. App. Div. 1999) ("Plaintiff requested 'proper and adequate' coverage . . . in response, the agent, as she had in prior years, utilized a 'Home Aestimator' computer program to check .... In the aftermath of a fire at the insured premises, plaintiff discovered that, in fact, he had been seriously underinsured ...."). 
most valuable assets-their homes-are insured for" and that despite "nearly all" insurance companies capping coverage for an insured loss of a home, "More than two thirds (71 percent) of those surveyed believe insurance pays for the full cost to rebuild their property in the event of a major loss, such as a fire or other natural disaster." 72 Simply put, most Americans think they have more insurance than they actually have.

\section{THE PERVASIVENESS OF AMBIGUITY CONCERNING WHETHER THE INSURER OR THE HOMEOWNER BEARS THE RISK OF UNDERVALUATION RESULTING IN UNDERINSURANCE}

So how does this happen? How is it that half of America has less insurance coverage than it thinks it has? As described above, insurers have an incentive to understate the actual value of their homes, and that incentive plays out in a variety of ways in actual market transactions. ${ }^{73}$ If insurers act in accordance with this incentive, then homes are underinsured relative to their value even if the homeowner selects the optimal percentage of insured value. The insurance industry has a several-decade history of understating value.

Following World War II, the market for homes exploded, thus creating both mortgage lenders insisting on homeowner's insurance and the homeowner's insurance market. ${ }^{74}$ "Since homeowners were not prepared to [evaluate the cost of replacing a lost home], the insurance industry began to take an active and scientific role in establishing total replacement cost before losses actually occurred." ${ }^{, 75}$ But as market changes necessitated the revision of formulas, insurers were slow to react, resulting in underinsurance. ${ }^{76}$

Before 1994, when most residential insurance policies were "guaranteed replacement policies," insurers explicitly bore the responsibility for accurate valuation. "The history of homeowners' insurance business after World War II . . . eventually taught property writers that the financial viability of their business is directly linked to establishing accurate defendable insurable values for each risk insured." 77 In other words, in the context of guaranteed replacement, or de facto full insurance policies, the party bearing the responsibility for valuation also bore the cost from error in the calculation.

${ }^{72}$ Homeowners Coverage Knowledge Gap Wide Among Consumers, INSURANCE JOURNAL, Aug. 24, 2010, http://www.insurancejournal.com/news/national/2010/ 08/24/112704.htm.

${ }^{73}$ See Weston, supra note 1; Treaster, supra note 1; Neal, supra note 25; Chu \& Weise, supra note 1.

${ }^{74}$ WELLS, supra note 8 , at 7-12.

${ }^{75} \mathrm{Id}$. at 11 .

${ }^{76}$ Id. at $7-20$.

${ }^{77}$ Id. at 21 . 
Starting in 1994, in response to the perceived cost of providing nolimit insurance for a total loss, ${ }^{78}$ almost all insurers did away with "guaranteed replacement" policies. ${ }^{79}$ When guaranteed replacement coverage ceased to be the industry norm, this created both an increased incentive to undervalue a home, and ambiguity as to whether the insurer or the homeowner bore the risk of undervaluation.

Capped insurance coverage created, in the first instance, the possibility of underinsurance. By doing so, capped insurance increased the incentive to an insurer to understate property value. This is because capped coverage reduces the risk of valuation error to the insurer. ${ }^{80}$

Under guaranteed replacement policies, in the event of total loss, the carrier paid claims in excess of the base values upon which premium was calculated. The insurer bore the full cost of valuation error. Under capped policies, an insurer only bore this cost of error if, in the terminology of insurance law, the policy was "reformed" in the wake of loss (typically as a result of litigation) to provide coverage as if the value had been correctly stated. ${ }^{81}$

The elimination of guaranteed replacement coverage also created ambiguity about whether insurers or homeowners bore ultimate responsibility for errors in valuation. This ambiguity can be seen in the contrasting post-loss positions of homeowners and insurers. Homeowners perceive their brokers or agents to be experts on how much insurance is adequate. ${ }^{82}$ But brokers and agents contend their expertise is not risk valuation, but rather the nuances of policies and forms, and the

78 Insurance Services Office, The Impact of Catastrophes on Property Insurance, Jan. 1994, at 3.

${ }^{79}$ Weston, supra note 1; Treaster, supra note 1; Liz Pulliam, supra note 25; Daniel Schorn, Is Your Home UnderInsured?, CBS NEws, July 4, 2007, http://www.cbsnews.com/stories/2007/07/04/business/realestate/main3015665_p age2.shtml (last visited June 25, 2009); Neal, supra note 25; see also Everett v. State Farm Gen. Ins. Co., 162 Cal. App. 4th 649, 652 (Cal. Ct. App. 2008) ("In 1997, State Farm eliminated the guaranteed replacement cost coverage in its homeowners policies."). As of the time of this writing, one major insurer-Auto Club-still offered guaranteed replacement insurance.

${ }^{80}$ In the instance of capped coverage, the homeowner has contractually agreed to a particular figure as the coverage amount. This figure may or may not be indexed in the mind of the contracting parties to the value of the home, but nonetheless routinely is enforced by the courts. See infra Section E.

81 See, e.g., United Policyholders, Avoiding Underinsurance, Fall 2004, http://unitedpolicyholders.com/newsletters/fall04.html\#4 (last visited Jan. 14, 2011); United Policyholders, Underinsurance 101, Fall 2004, http://unitedpolicyholders.com/pdfs/UNDERINSURANCE101.pdf (last visited Jan. 14, 2011).

${ }^{82}$ Treaster, supra note 1 , at A1. 
resulting differences between various insurance policies. ${ }^{83}$ As a spokesman for Insurance Information Network of California said in the wake of the 2003 California wildfires, "IIt's ultimately up to the homeowners to try to ascertain if [the coverage] is enough." "84 The American Insurance Association argues that "it really is the homeowner who is in the best position" to know what coverage is needed. ${ }^{85}$ Identical arguments are made by the Association of California Insurance Companies and the Personal Insurance Federation of California. ${ }^{86}$

\section{E. ONE APPROACH TO ELIMINATING INSURER RESPONSIBILITY FOR UNDERVALUATION}

One would predict that a rational insurer would, if it could, eliminate any potential insurer responsibility for undervaluation, and do so in a way that would not cause the customer to choose a different insurer. That prediction is borne out by a clause now found in some insurance policies.

The clause and its mechanism are illustrated by the case of Everett $v$. State Farm General Insurance Co ${ }^{87}$ From 1991 to 1997, Agnes Everett's home was insured by State Farm with guaranteed replacement cost coverage ${ }^{88}$ In 1997, State Farm provided written notification to Ms. Everett that her policy was being changed to limit replacement coverage. ${ }^{89}$ That renewal provided a specific amount of "replacement

\footnotetext{
${ }^{83}$ Beisiegel, supra note 1 , at 21.

${ }^{84}$ Spagat, supra note 1; see also Treaster, supra note 1, at Al (quoting a representative of the Insurance Information Institute saying, "It's the homeowner's responsibility to see that his home is properly insured"'); Liz Pulliam, supra note 25, at D1 (quoting a spokesperson for Framers Insurance, "The consumer has the responsibility to determine what their coverage should be”"); Smith v. Kert LeBlanc Ins. Agency Inc., 2008 WL 2308828, at *1 (E.D. La. 2008) ("[A]ccording to State Farm, ... . [it is the homeowner] upon whom the duty rested to advise their insurer of any necessary increase in coverage.").

${ }^{85}$ Letter from American Insurance Association to Honorable Ronald M. George, Chief Justice, California Supreme Court (July 7, 2008).

${ }^{86}$ Letter from Association of California Insurance Companies and Personal Insurance Federation of California to Honorable Ronald M. George, Chief Justice, California Supreme Court (June 25, 2008); Letter from Association of California Insurance Companies and Personal Insurance Federation of California to Honorable Ronald M. George, Chief Justice, California Supreme Court (July 2, 2008). For the perspective of the policyholder on Everett, see Lee Harris, Does Everett v. State Farm Shut the Door on Underinsured Homeowners?, ForUM, Nov./Dec. 2008, at 17.

${ }^{87}$ Everett v. State Farm Gen. Ins. Co., 162 Cal. App. 4th 649, (Cal. Ct. App. 2008).

${ }^{88}$ Id. at 652 .

${ }^{89}$ Id. at $652-53$.
} 
cost" coverage should Ms. Everett suffer a total loss of her home. ${ }^{90}$ For the next six years, each annual renewal statement from State Farm to Ms. Everett stated:

The State Farm replacement cost is an estimated replacement cost based on general information about your home. It is developed from models that use cost of construction materials and labor rates for like homes in the area. ${ }^{91}$ The actual cost to replace your home may be significantly different. State Farm does not guarantee that this figure will represent the actual cost to replace your home. You are responsible for selecting the appropriate amount of coverage and you may obtain an appraisal or contractor estimate which State Farm will consider and accept, if reasonable. Higher coverage amounts may be selected and will result in higher premiums. ${ }^{92}$

In October of 2003, Ms. Everett lost her home to wildfire. ${ }^{93}$

The resulting litigation reflects that the clause had the effect, at least in the one litigated instance, of eliminating risk to State Farm of undervaluation, without creating risk to State Farm of losing a customer. At trial, State Farm successfully pointed to and relied upon the policy language, "You are responsible for selecting the appropriate amount of coverage. ${ }^{.94}$ Yet State Farm almost certainly never was at risk of losing Ms. Everett as a customer, since if Ms. Everett ever read the language, she would have understood State Farm to be discouraging her from questioning the adequacy of her coverage. After all, State Farm told her that it had calculated the cost of rebuilding her home and if she wanted to ask State Farm for more insurance, then she would have to spend money and hire professionals to support why she wanted more insurance. Even then, State Farm might not agree to give her more insurance, and if State Farm did agree, then that would cost her yet more money. In the face of the State Farm clause, Ms. Everett believed she was entitled to full replacement coverage, without regard to policy limits. $^{95}$

${ }^{90}$ Id. at $653-54$.

91 Although it is not clear from the published Opinion, almost certainly the "model" used was the Marshall \& Swift "quick quote" function, which calculates cost using only zip code, square footage, and year of construction.

${ }^{92}$ Everett, 162 Cal. App. 4th at 653.

${ }^{93} \mathrm{Id}$. at $653-54$.

${ }^{94} \mathrm{Id}$. at $652-53$.

${ }^{95} \mathrm{Id}$. at 654 . 


\section{F. THE INCENTIVES TO UNDERINSURE HAVE CREATED MARKET INEFFICIENCIES}

Summarizing the preceding sections, we see that while a large and increasing percentage of homeowners wish to fully insure, insurers perceive that "[a]n insurer willing to pay the price of sufficient catastrophe insurance could have trouble competing for business." ${ }^{.96}$ This frames something akin to a prisoner's dilemma for insurers. Insurers are competing against each other for a fixed number of customers in a largely mature market (most potential customers already are actual customers). Insurers see the market largely as commoditized. Using sound actuarial principles to calculate premium should yield roughly the same premium for all insurers. While an insurer may have an economic incentive to use less sound, more aggressive actuarial principles, insurance is a regulated product requiring state approval of the actuarial soundness of an insurance product. The other variable in setting price is the "valuation" of the home. And here lies the "prisoner's dilemma." If an insurer could depend upon competitors to do accurate valuations, then the insurer is not at risk of losing market share on the basis of valuation approach. Otherwise, the insurer has an incentive to adopt two strategies: (1) devise "valuation" formulas that support lower valuation than those of one's competitors without putting the actuarial soundness of the business at risk, and (2) shift the risk of underinsurance due to undervaluation to the homeowner in a manner that does not change price.

The products of Marshall \& Swift/Boeckh (the producer of the predominant valuation tools) assume that while there are many ways to calculate valuation, there is only one, objectively accurate valuation. ${ }^{97}$ Insurance brokers and agents certainly would debate this assertion, viewing valuation as much more art than science-and a potentially prohibitively time-consuming art at that. In other words, in writing new business, with enough time and attention, agents and brokers could value a home into a relatively tight range, but the time dedicated to each home

${ }^{96}$ Insurance Services Office, Managing Catastrophe Risk, May 1996, http://www.iso.com/Research-and-Analyses/Studies-and-Whitepapers/Managing -Catastrophe-Risk.html; see also WELLS, supra note 8, at 43 ("As the industry moved closer to capped policy limits, making certain that the policy limits included all of the costs faced when losses occurred [would charge] . . . premiums commensurate with the entire risk assumed.").

${ }^{97} \mathrm{http} / / / \mathrm{msbinfo} . c 0 m /$ Solutions (last visited Apr. 14, 2011) ("Our products, methods and data help take the guesswork out of risk selection and pricing and help you truly see risks for what they are"); http://msbinfo.com/Solutions/RiskS election/InsuranceToValue (last visited Apr. 14, 2011) ("We base this approach on the concept that a building's unique features, rather than its square footage, determine its actual reconstruction cost"); see also WeLLS, supra note 8, at v ("This new text ... helps carriers identify the true value of each individual risk"). 
would be inconsistent with a successful business model, even assuming customers would stand for it. The problem would be even worse in the instance of renewed basis, as it would be inconsistent with the idea of a seamless renewal process.

If an insurer has to choose between likely undervaluation and likely overvaluation, the rational strategy is to either intentionally promote or passively allow an undervaluation. Property insurance is highly price elastic, so overvaluation inevitably will result in fewer customers. By contrast, if most homes do not have an insured loss at all in a coverage year, and less than two percent of claims are total loss claims, then a home fully insured to stated value - but actually undervalued-is unlikely to experience a loss in excess of coverage, and in turn an unhappy customer who does not renew the policy (even assuming the insurer wishes this customer to renew). The only real risk to an insurer is that a loss in excess of coverage will occur, and that the insurer will be held responsible for the shortfall. ${ }^{98}$ That risk is perceived by the insurers to be low, even in the face of mass loss from, for example, natural disaster: "Large catastrophes are rare; therefore, an insurer that does not have high catastrophe limits is likely to survive." 99

But the benefit of this approach can be enhanced if the insurer can shift the risk of underinsurance due to undervaluation onto the homeowner, and do so in a manner that does not raise prices. The challenge is that in a commoditized marketplace, even a homeowner who wants "full" insurance will select his insurer by picking the cheapest insurance. If the insurer discloses to the homeowner that what really is being offered is "full" insurance of only $80 \%$ of the house, then the insurer may well lose that customer. ${ }^{100}$ The consequence is an incentive to have a home that is undervalued, and a homeowner who in making the purchase decision is not accounting for the risk of undervaluation. This is, in essence, the Everett clause.

Two inefficiencies result:

(1) Inadequate information impairing informed pricing decisions by purchasers.

${ }^{98}$ One might quarrel with the morality of such a strategy, but at this juncture this Article simply is laying out the rationality of such a strategy.

${ }^{99}$ Insurance Services Office, supra note 96.

${ }^{100}$ There is a joke about a hungry traveler who, upon stopping at a roadside restaurant that has a huge sign advertising it is "Open 24 Hours," encounters the restaurant owner locking the doors and closing for the evening. When the now distraught traveler asks about the sign, the owner responds, "The sign doesn't say which 24 hours!" 
(2) Dispute costs (such as litigation) in the instances of loss exceeding coverage.

There is some limited data available to quantify the cost of inadequate information impairing informed pricing decisions by purchasers. This inaccessibility of contract language to consumers is an understood dynamic in lengthy insurance contracts. The length of insurance policies, and the lack of prominence of the disclosure, can utterly defeat any effectiveness it otherwise might have. ${ }^{101}$ Homeowners are not fully aware of how their coverage is calculated, or what their policy says or means. ${ }^{102}$ Compounding the policy's lack of clarity, the homeowner typically does not even get his full insurance policy until long after the policy is purchased. ${ }^{103}$

101 Schwarcz, supra note 15, at 1399 (citing DAvid G. OwEN, Products LIABILITY LAW 589-92 (Thomson West 2005)); Howard Latin, "Good" Warnings, Bad Products, and Cognitive Limitations, 41 UCLA L. REV. 1193, 1195, 1198 (1994); A.D. Twerski et al., The Use and Abuse of Warnings in Products Liability-Design Defect Litigation Comes of Age, 61 CoRNELL L. REV. 495, 511-16 (1976); W. Kip Viscusi, Individual Rationality, Hazard Warnings, and the Foundations of Tort Law, 48 RUTGERS L. REV. 625, 627 (1996); Richard Craswell, Taking Information Seriously: Misrepresentation and Nondisclosure in Contract Law and Elsewhere, 92 VA. L. REV. 565, 583-84 (2006).

102 See Robert H. Jerry, II, Understanding Insurance Law $§ 32$ [b] (Matthew Bender 2d ed. 1996) ("[A]n insured relies not upon the text of the policies but upon the general descriptions of the coverage provided by the insurer and its agents."); Todd D. Rakoff, Contracts of Adhesion: An Essay in Reconstruction, 96 HARV. L. REV. 1173,1179 (1983); see also, WELLS, supra note 8 , at 53 (it is believed in the industry that consumers have "no real understanding of the value of their structures or the pricing variables that determine[] their rates").

${ }^{103}$ See, e.g., Robert E. Keeton, Insurance Law Rights at Variance With Policy Provisions, 83 HARV. L. REV. 961, 968 (1970) (explaining that "the normal processes for marketing most kinds of insurance do not ordinarily place the detailed policy terms in the hands of the policyholder until the contract has already been made. In life insurance marketing, for example, the policyholder does not ordinarily see the policy terms until he has signed the application (his offer to contract with the company) and has paid a premium, and the company has approved the application and has executed and issued the policy. This often means a delay of weeks, and occasionally even longer, between making an application and having possession of the policy-a factor enhancing the policyholder's disinclination to read his policy carefully or even to read it at all"); Michelle E. Boardroom, Contra Proferentem: The Allure of Ambiguous Boilerplate, $104 \mathrm{MICH}$. L. REV. 1105, 1106 (2006) ("[I]nsurance contracts typify the modern consumer contract--boilerplate clauses, little negotiation, written in legalese, and received by the consumer only after the contract has begun."). Insurers also have asserted that policy language can equate to a counter-offer, which the insured then accepts by retaining the policy and paying the premiums. 
Each year hundreds of millions of dollars of uninsured losses result from unintended underinsurance. The California Department of Insurance reports there were 5817 residential insurance claims resulting from the November 2008 firestorms in Central California. ${ }^{104}$ The 5817 claims resulted in over $\$ 610,000,000$ in direct incurred loss, only roughly $75 \%$ of which was paid. ${ }^{105}$ This means that roughly $\$ 150,000,000$ in incurred losses (meaning losses which the insurer felt were sufficiently credibly covered claims that the insurer reserved against them) were losses where the homeowner claimed coverage, and the insurer denied it.

The same firestorms resulted in 733 total loss claims. ${ }^{106}$ We can assume that the vast bulk of the $\$ 150,000,000$ arose in those cases.

As many as $50 \%$ of insured homes think they have "full" insurance. ${ }^{107}$ The one-year survey of United Policyholders found that $51 \%$ of homeowners reported, after loss, that they were either "very unsatisfied" or "unsatisfied" with the adequacy of their insurance coverage in the wake of loss. ${ }^{108}$ In other words, undervaluation, even very conservatively calculated, caused an unexpected, uninsured loss due to underinsurance of tens of millions of dollars in 733 homes. In an average year, across the Nation, there are in excess of 30,000 homes that are totally lost to disaster. ${ }^{109}$ The United Policyholders survey of survivors of the 2007 Southern California firestorms reported the average amount of underinsurance to be $\$ 240,000{ }^{110}$

Appellee's Brief at *6, Cheek v. State Farm Fire \& Cas. Co., No. 95-56601, 1996 WL 33486441 (9th Cir. Apr. 4, 1996).

104 California Department of Insurance, Estimate of Summary Loss Data Resulting from the November 2008 Southern California Fires, Data as of May 10, 2009.

${ }^{105} \mathrm{Id}$.

${ }^{106} \mathrm{Id}$.

${ }^{107}$ See supra section II.C.1.

108 See one-year survey results data at United Policyholders, Southern California Wildfire Claim Survey Results, http://www.uphelp.org/pdfs/OneYear SurveyResults2009.pdf (last visited Feb. 28, 2011).

${ }^{109}$ This is the average of American Housing figures over the last decade. In $2007,41,000$ homeowners of owner-occupied units reported that they moved from their home because of a "Disaster loss (fire, flood, etc.)." 2007 Housing SURVEY tbl 3-11, supra note 6. In 2005, it was 22,000. U.S. CENSUS BUREAU, AMERICAN HOUSING SURVEY FOR THE UNITED STATES: 2005, tbl.3-11. In 2003, it was 34,000. U.S. CEnsus BurEau, AmERICAN Housing Survey For tHE UNITED STATES: 2003, tbl.3-11. In 2001, it was 22,000. U.S. CENSUS BurEaU, AMERICAN HOUSING SURVEY FOR THE UNITED STATES: 2001, tbl.3-11.

110 See six-month survey results data at United Policyholders, Southern California Wildfire Claim Survey Results, http://unitedpolicyholders.org/survey/ surveyresults.html (last visited Feb. 28, 2011). 
The cost of dispute resolution is harder to quantify. ${ }^{111}$ The cost can arise in at least three ways: (1) extended and contentious claims resolution that does not result in external dispute resolution mechanisms; (2) complaints and requests for intervention to external entities (such as a state Department of Insurance) that do not result in litigation; and (3) litigation. A survey from United Policyholders calculates the frequency of unsuccessful claims negotiations as $64 \% .{ }^{112}$ As discussed above, about $20 \%$ of these instances resulted in complaints to the Department of Insurance. ${ }^{113}$ Even a cursory survey of reported legal decisions reveals a lot of litigation disputes over the causes of and responsibility for underinsurance. ${ }^{114}$ It is hard to know with precision, however, just how

111 For a broader discussion of the cost of litigation as a tool of insurance regulation, see KENNETH S. ABRAHAM, The Insurance Effects of Regulation by Litigation, in REGULATION THROUGH LITIGATION 212-43 (W. Kip Viscusi ed., AEI-Brookings Joint Center for Regulatory Studies 2002).

${ }_{112}$ See Southern California Wildfire Claim Survey Results, supra note 110.

${ }^{113}$ See supra text accompanying notes 66-67.

${ }^{114}$ See, e.g., Free v. Republic Ins. Co., 8 Cal. App. 4th 1726, 1729 (Cal. Ct. App. 1992) ("According to the complaint,... [in 1979] and every succeeding year [until 1989] . . . appellant contacted [the insurance representative] to inquire whether the coverage limits if his policy were adequate to rebuild his home. On each occasion, he was informed they were."); Cheek v. State Farm Fire \& Cas. Co., 110 F.3d 67 (9th Cir. 1997) ("The Cheeks Complaint alleged that State Farm was negligent in failing to provide them with a certain level of earthquake coverage, as they had specifically requested ...."); Opening Brief of Appellant at 5, Aslan v. State Farm Fire \& Cas. Co., 125 F.3d 857 (9th Cir. 1996) ("Respondent assured Kenneth Asian [sic] that his earthquake policy was sufficient ...."); Desai v. Farmers Ins. Exchange, 47 Cal. App. 4th 1110, 1114 (Cal. Ct. App. 1996) ("Desai informed an insurance vendor, Carol Sacramone Insurance Agency, that he wanted 100 percent coverage . . . . Sacramone told Desai that Farmers Insurance Group offered the type of insurance Desai wanted, and orally represented that the policy provided ' 100 [percent] coverage ...'.'); White v. Allstate Ins. Co., 513 F. Supp. 2d 674, 677 (E.D. La. 2007) ("Plaintiffs further allege that Tarleton indicated that the hurricane coverage under their homeowner's policy would cover any and all damages that might be incurred as a result of a hurricane."); Cameron Parish Sch. Bd. v. State Farm Fire \& Cas. Co., 560 F. Supp. 2d 485, 487 (W.D. La. 2008) ("In its Complaint, CPSB alleges that State Farm knew CPSB's flood insurance was insufficient, that State Farm knew CPSB wanted to maximize its flood insurance, and that State Farm did not tell CPSB additional flood insurance could be purchased outside of the NFIA and with another company."); Smith v. Kert LeBlanc Ins. Agency, Inc., 2008 WL 2308828, at *1 (E.D. La. 2008) ("Plaintiffs contend that they should be paid more than their policy limits because State Farm did not advise them upon renewal of their policy that the amount of their coverage would be insufficient to completely rebuild their home following its destruction .... . Plaintiffs argue that they specifically desired and purchased a 'full replacement policy."'); Martinonis v. Utica Natl. Ins. Group, 840 N.E.2d 994, 996 (Mass. App. 2006) ("'I definitely brought up to him all of this information, and questioned him and asked him and asked him whether it shouldn't be increased. 
large the burden of dispute resolution is. Many claims do not result in litigation, ${ }^{115}$ and many litigation claims do not go to trial or become reported appellate decisions.

\section{A HISTORY OF LEGISLATIVE AND JUDICIAL RESPONSES TO INFORMATION INEFFICIENCIES IN INSURANCE TRANSACTIONS}

Both of the inefficiencies identified above result from imperfect information. Homeowners have less insurance than they expect when they have imperfect information about valuation. Disputes arise when the distribution of the risk of inaccurate valuation is unclear.

Expressed another way, when a homeowner purchases residential property insurance, the determination of coverage, valuation, and apportionment of risk (of either underinsurance or undervaluation) will result in one of five scenarios:

(1) Homes with guaranteed replacement coverage.

(2) Homes with capped coverage that are correctly valued and have full insurance.

(3) Homes with capped coverage that are correctly valued, are insured for less than full value, and both insurer and homeowner are adequately informed (A) that in the event of loss the coverage may be less than the cost to rebuild, and (B) of the apportionment, between insurer and homeowner, of responsibility for any shortfall of coverage to fund rebuilding of the home.

(4) Homes with capped coverage that are correctly valued, are insured for less than full value, and the homeowner (and perhaps the insurer) is inadequately informed (A) that in the event of loss the coverage may be less than the cost to rebuild, or (B) of the apportionment, between insurer and homeowner, of responsibility for any shortfall of coverage to fund rebuilding of the home.

And he reassured me that that should be adequate."'); Stevens v. Hickey-Finn \& Co., Inc., 261 A.D.2d 300, 300-01 (N.Y. App. Div. 1999) ("Plaintiff requested 'proper and adequate' coverage ... in response, the agent, as she had in prior years, utilized a "Home Aestimator' computer program to check .... In the aftermath of a fire at the insured premises, plaintiff discovered that, in fact, he had been seriously underinsured . . .. "); Everett v. State Farm Gen. Ins. Co., 162 Cal. App. 4th 649, 656-58 (Cal. Ct. App. 2008).

${ }^{115}$ See David J. Nye \& Donald G. Gifford, The Myth of the Liability Insurance Claims Explosion: An Empirical Rebuttal, 41 VAND. L. REV. 909, 910 (1988). 
(5) Homes with capped coverage that are undervalued and the homeowner (and perhaps the insurer) is inadequately informed (A) that in the event of loss the coverage may be less than the cost to rebuild, or (B) of the apportionment, between insurer and homeowner, of responsibility for any shortfall of coverage to fund rebuilding of the home.

Scenarios (1) and (2) do not lead to either of the inefficiencies identified in this Article. Because scenario (3) only requires objectively, not subjectively, adequate information, there may still be some instances of either of the described inefficiencies, but the frequency and cost will be greatly reduced. This Article thus targets scenarios (4) and (5).

The problem of clearly conveying information in insurance contracts is not news. ${ }^{116}$ Legislatures and courts are no strangers to the problems that flow from the difficulty consumers have in understanding their insurance policies. Both institutions have tried to address the problem of inadequate information through the jurisprudence of contracts.

Legislatures have adopted a variety of approaches to impose clarity and disclosure on the purchase and sale of various insurance products. For homeowners' insurance, the predominant tool of choice is the Flesch Readability Index. ${ }^{117}$

In 1948, Rudolph Flesch published a methodology to measure the ease of understanding a statement written in English. ${ }^{118}$ It is used by numerous government agencies, including the United States Department of Defense. ${ }^{119}$ In other words, the Flesch Readability Index, properly applied, is a recognized metric of language clarity.

While in principle, the states' adoption of the Flesch readability metric is a rational response to the lack of clarity in insurance transactions, in practice the adoption falls short. Twenty-five states, as well as the District of Columbia, require that at least some types of insurance policies (most often, but not always, homeowners' policies)

116 See, e.g., Symposium, Introduction: The Insurance Law Doctrine of Reasonable Expectations After Three Decades, 5 CONN. INS. L.J. 1 (1998).

117 New Mexico has a more general requirement of policy language simplification. N.M. STAT. ANN. (1978) \& 59A-19-4(A)(1). South Carolina requires Flesch readability at a seventh grade reading level while Texas requires a ninth grade reading level. S.C. CODE ANN. § 37-4-105(B) (1976); 28 TEX. ADMIN. CODE \$3.3092(c)(2) (1997). Connecticut requires a particular font size. CONN. AgENCIES Regs. \& 38a-430-2 (2009).

${ }^{118}$ Rudolf Flesch, A New Readability Yardstick, 32 J. APPL. PsYCH. 221 (1948).

119 Readability Formulas, The Flesch Reading Ease Readability Formula, http://www.readabilityformulas.com/flesch-reading-ease-readability-

formula.php (last visited Feb. 28, 2010). 
have a minimum "Flesch readability score" of either 40 or $45 .{ }^{120}$ Three states require a Flesch readability score of at least $50 .{ }^{121}$ The Flesch formula divides the ease of readability of language into the following categories: Very Easy, Easy, Fairly Easy, Standard, Fairly Difficult, Difficult, and Very Difficult. ${ }^{122}$ Language is in the second lowest category-Difficult-if it has a score between 30 and $49 .{ }^{123}$ In other words, rather than utilize the Flesch metric to mandate readable insurance policies, state legislatures use the metric to permit policies that are at least "difficult" to understand—or, put another way, simply not "very difficult."

The judicial response to insurance coverage disputes also approaches the question from the premise that insurance policies are contracts, and thus subject to traditional contract doctrines and tools to refine clarity. ${ }^{124}$ Cases such as Everett illustrate the resulting problem of a traditional contract analysis. State Farm asserted successfully that it had clearly and effectively shifted risk. ${ }^{125}$ Yet Ms. Everett plainly had not gotten that message. And this is not simply because either she did not read her policy or was too unsophisticated to understand it. Ms. Everett's circumstances, and how State Farm dealt with them, resulted in a sufficiently problematic legal outcome that the California Insurance Commissioner supported de-publication of the Everett appellate

${ }^{120}$ ARIZ. ADMIN. CODE $\S$ R20-6-210(C)(2) (2009); ARK. CODE ANN. § 23-80206(a)(1) (West 2010); 3 Colo. CODE REGS. $\$ 702-4$ (2011); D.C. Code $\S 31$ 4725(a)(1) (2009); FLA. STAT. ANN. §627.4145(1)(a) (West 2009); GA. CoMP. R. \& REGS. 120-2-42.04(g) (2009); IND. CODE ANN. §§ 27-1-13-16(b)(3) \& $27-$ 1-26-3(1) (West 2009); IOWA ADMIN. CODE r. 191-28.14(2) (2009); 806 KY. ADMIN. REGS. 14:121(5)(1) (2009); MD. CODE REGS. 31.10.02.02(A)(1) (2009); MinN. Stat. AnN. § 72C.10(2)(a) (West 2009); MonT. CodE ANN. § 33-15337(8) (West 2007); NeB. REV. STAT. ANN. § 44-3405(1)(a) (2008); NEV. REV. STAT. ANN. $\S$ 687B.124(1)(a) (West 2008); N.J. AdMIN. CODE $\S 11: 2-18.4(\mathrm{j})$ (2009); N.Y. INSURANCE LAW $\S 3102(c)(1)(D)$ (McKinney 2009); N.D. CENT. CODE $§ 26.1-33-30(1)$ (a) (2008); OHIO REV. CODE ANN. $§ 3902.04(A)(1)$ (West 2009); OKLA. STAT. ANN. tit. 36, § 3645(A)(1) (West 2009); Or. REV. Stat. ANN. $\S 743.106(1)$ (a) (West 2009); S.D. CoDIFIED LAWS $\S$ 58-11 A-3(1) (2009); TENN. CODE ANN. $§ 56-7-1605$ (a)(1) (West 2009); VT. ADMIN. CODE 4-3-10:6 (West 2010); VA. CODE ANN. § 38.2-233(G) (West 2009); W. VA. CODE ANN. § 33-29-5(a)(1) (West 2009); WIS. ADMIN. CODE INS. § 6.07(4)(a)(1) (2009). All but two of these states-Florida and New York-set the threshold at 40, rather than 45 .

${ }^{121}$ ME. Rev. STAt. AnN. tit. 24-A, § 2441(1)(A) (2009); 211 MA. Code Regs. 71.04(1) (2009); N.C. GEN. STAT. ANN. § 58-38-30(b)(1) (West 2009).

${ }^{122}$ Flesch, supra note 118 , at 230.

${ }^{123} \mathrm{Id}$.

${ }^{124}$ See, e.g., Pardee Constr. Co. v. Ins. Co. of the West, 77 Cal. App. 4th 1340, 1352 (Cal. Ct. App. 2000).

${ }^{125} 162$ Cal. App. 4th at 654-63. 
decision. ${ }^{26}$ Traditional contract doctrines left sufficient ambiguity, even with State Farm's clause, for credible and costly litigation to ensue.

Special contract doctrines crafted to address insurance contracts in particular have fared no better. For example, in 1970, the legendary Robert Keeton proposed biasing the interpretation of contracts to favor the reasonable expectations of the insured. ${ }^{127}$ This approach was adopted in some form by at least half of the states. ${ }^{128}$ Under the doctrine, insureds get the coverage they reasonably expect without regard to the verbiage of the policy. ${ }^{129}$ Keeton saw it as a way to avoid precisely the kind of problem this Article is addressing: after-the-fact surprises about the sufficiency of coverage. ${ }^{130}$ The doctrine grew out of the commonsense but probably inaccurate notion that because insurance contracts could be thought of as contracts of adhesion, normal market mechanisms to encourage efficient contracting failed. ${ }^{131}$ As a matter of jurisprudence and economics, the advisability of this approach has been debated. ${ }^{132}$

Most states, however, have used the doctrine in a far less aggressive way, such as a proxy for ordinary contract principles. ${ }^{133}$ In any event, the doctrine suffered from a host of problems in application. ${ }^{134}$ Today, few states follow the rule, and the case law describing it is convoluted. ${ }^{135}$

A second approach in the courts has been the special duty doctrine. This approach starts from the premise that insurance is a contract just

${ }^{126}$ June 25, 2008 Request of California Insurance Commissioner Steve Poizner for Depublication of Everett v. State Farm General Ins. Co., 162 Cal. App. 4th 649 (Cal. Ct. App. 2008).

${ }^{127}$ Keeton, supra note 103, at 966-77.

${ }^{128}$ Steinberg v. Nationwide Mut. Ins. Co., 224 F.R.D. 67, 77 (E.D.N.Y. 2004).

${ }^{129}$ Keeton, supra note 103; see, e.g., Buss v. Superior Court, 16 Cal. 4th 35, 45 (Cal. 1997) ("To yield their meaning, the provisions of a policy must be considered in their full context .... Where it is clear, the language must be read accordingly .... . Where it is not, it must be read . . . in the sense that satisfies the insured's objectively reasonable expectations.").

${ }^{130}$ Keeton, supra note 103 , at $967-68$.

${ }^{131}$ Schwarcz, supra note 15, at 1401-02.

132 See Mark C. Rahdert, Reasonable Expectations Reconsidered, 18 CONN. L. REV. 323 (1986); Kenneth S. Abraham, Judge-Made Law and Judge-Made Insurance: Honoring the Reasonable Expectations of the Insured, 67 VA. L. REV. 1151 (1981); Richard Craswell, Passing on the Costs of Legal Rules: Efficiency and Distribution in Buyer-Seller Relationships, 43 STAN. L. REV. 361 (2009); David F. Travella, Are Insurance Policies Still Contracts?, 42 CREIGHTON L. REV. 157 (2009).

${ }^{133}$ Schwarcz, supra note 15 , at 1427-28.

${ }^{134}$ See, e.g., Abraham, supra note 132, at 1152 (arguing against the doctrine); Symposium, The Insurance Law Doctrine of Reasonable Expectations After Three Decades, 5 CoNN. INS. L.J. 1 (1998).

${ }^{135}$ Schwarcz, supra note 15 , at 1395. 
like any other contract. ${ }^{136}$ Thus, because policy coverage limits are explicitly set forth in the contract, the insurer and its representatives have no general duty to make sure that the limits are adequate unless their actions create a special relationship and duty to do so. ${ }^{137}$ Yet in the end, this approach too was unsuccessful. As one writer summarized the point, "the courts' fixation on the concepts of 'contract of adhesion' and 'bargaining disparity' has caused the judiciary to misidentify the problem," which actually "is with information imbalance."

\section{Legislative Proposal}

Courts and legislatures have explored, without success, various contract doctrines in order to address inadequate information in insurance transactions. ${ }^{139}$ The challenge is to identify a mechanism that discloses information more effectively without unnecessarily impairing the ability of competitors to compete. To address the inadequacy of information in insurance transactions, courts and legislatures must broaden the scope of inquiry beyond insurance contract jurisprudence.

\section{A. METHODS OF CURING INFORMATION INADEQUACY}

A variety of non-insurance consumer contracts mandate language, font, and prominence of information within a contract, such as the detailed disclosures and consents sometimes mandated in real estate sales contracts. ${ }^{140}$ But as discussed above, there is little history of these

${ }^{136}$ See, e.g., Bank of the West v. Superior Court, 2 Cal. 4th 1254, 1264 (Cal. 1992) ("While insurance contracts have special features, they are still contracts to which the ordinary rules of contractual interpretation apply.").

137 See, e.g., Stokes v. Harrell, 711 S.W.2d 755, 756 (Ark. 1986); Free v. Republic Ins. Co., 8 Cal. App. 4th 1726, 1729-30 (Cal. Ct. App. 1992); Filip v. Block, 879 N.E.2d 1076, 1085-86 (Ind. 2008); Bichelmeyer Meats v. Atlantic Ins. Co., 42 P.3d 1191, 1197 (Kans. App. 2001); Smith v. Kert LeBlanc Ins. Agency Inc., 2008 WL 2308828, at *1-3 (E.D. La. 2008); Szelenyi v. Morse, Payson \& Noyes Ins., 594 A.2d 1092, 1094 (Maine 1991); Martinonis v. Utica Natl. Ins. Grp., 65 Mass. App. Ct. 418, 420-21 (Mass. App. Ct. 2006); accord White v. Allstate Ins. Co., 513 F. Supp. 2d 674, 683 (E.D. La. 2007); Sandbulte v. Farm Bureau Mut. Ins. Co., 343 N.W.2d 457, 464 (Iowa 1984); Hill v. Grandey, 321 A.2d 28, 34 (Vt. 1974).

${ }_{138}$ James M. Fischer, Why Are Insurance Contracts Subject to Special Rules of Interpretation? Text Versus Context, 24 ARIZ. ST. L.J. 995, 1047 (1992) (quoted in Schwarcz, supra note 15, at 1403).

${ }^{139}$ See Schwarcz, supra note 15.

${ }^{140}$ See Appendix C to this Article for an example of various clauses of real estate contracts mandated under California law. For examples of such an approach in other consumer contracts, see California regulations addressing disclosure and risk arises in product tanning (CAL. BUS. \& PROF. CODE $§ 22701$ et seq.), dating ad weight loss contracts (CAL. CIV. CODE $\S 1694.2$ ), and Sperm/Ova removal (CAL. Bus. \& PROF. CODE $\S 2260$ ). More broadly, see Alan 
approaches working in insurance contracts. ${ }^{141}$ Just three of the problems are the length of the contracts, the turgid language used, and the timing of delivery of the written policy after the policy issues. ${ }^{142}$

Recent scholarship suggests an alternative approach, which argues for the entire abandonment of the predicate of insurance as contract. ${ }^{143}$ One very familiar example of an extra-contractual approach to information inadequacy is the product warning label on cigarettes. But, of course, the cigarette label itself demonstrates that not all product disclosure labels meet the goal of effectively and clearly disclosing critical information without unnecessarily impairing the ability of competitors to compete. Cigarette warnings labels, at least as configured in the United States, do not clearly and effectively convey information to consumers. ${ }^{144}$ While the Supreme Court has recognized that the labels do provide some limited tort liability immunity, ${ }^{145}$ some argue that the labels' failure has promoted more litigation as a means of curbing smoking. ${ }^{146}$ Put another way, cigarette warning labels do not seem to have ceased litigation nor clearly disclosed critical information.

Schwartz \& Louis L. Wilde, Imperfect Information in Markets for Contract Terms: The Examples of Warranties and Security Interests, 69 VA. L. REV. 1387 (1983).

${ }^{141}$ An anecdotal report of the ineffectiveness of such approaches is described in Debra Cassens Weiss, Judge Posner Admits He Didn't Read Boilerplate for Home Equity Loan, ABA JOURNAL LAW NEWs Now (June 23, 2010), http://www.abajournal.com/weekly/article/judge_posner_admits_he_didnt_read boilerplate_for_home_equity_loan.

${ }^{142}$ For a discussion of the intractability of crafting clear disclosures in complex contracts, see Debra Pogrund Stark \& Jessica M. Choplin, A Cognitive and Social Psychological Analysis of Disclosure Laws and Call For Mortgage Counseling to Prevent Predatory Lending, 16 PSYCH. PuB. POL. \& LAW 85, 96 $105(2010)$.

${ }^{143}$ See Schwarcz, supra note 15 , at 1434-62. A thoughtful discussion about the intersection of insurance and contract law, and where Professor Schwarcz's scholarship fits into that arc, is Jeffrey W. Stempel, The Insurance Policy As Thing, 44 TORT TRIAL \& INS. PRAC. L.J. 813 (2009); see also Jeffrey W. Stempel, The Insurance Policy as Social Instrument and Social Institution, 51 WM. \& MARY L. REV. 1489 (2010).

144 D. Hammond, G. T. Fong, A. McNeill, R. Borland \& K. M. Cummings, Effectiveness of Cigarette Warning Labels in Informing Smokers about the Risks of Smoking: Findings from the International Tobacco Control (ITC) Four Country

Survey, 15 TOBACCO CONTROL (2006), available at http://www.ncbi.nlm.nih.go $\mathrm{v} /$ pmc/articles/PMC2593056.

${ }^{145}$ Cipollone v. Liggett Grp., 505 U.S. 504, 520-21 (1992).

${ }^{146}$ Graham E. Kelder, Jr. \& Richard A. Daynard, The Role of Litigation in the Effective Control of the Sale and Use of Tobacco, 8 STAN. L. \& POL'Y REV. 63 (1997). 
The relationship of cigarette warning labels to consumer behavior is a highly nuanced and complex problem, and can be interpreted in a variety of ways. The point simply is this: not all product warning labels are of equal dignity or easily measured efficacy.

The approach this Article adapts is one already demonstrated as effective: ${ }^{147}$ the EnergyGuide program promoting energy efficiency in home appliances. ${ }^{148}$ The EnergyGuide program mandates the now ubiquitous yellow label "to maintain uniformity for immediate consumer recognition and readability.",149

\section{B. A PROPOSAL TO CURE INFORMATION INADEQUACY IN HOMEOWNER'S INSURANCE}

The essential qualities of the EnergyGuide label are its clarity, simplicity, and focus. Through simple text and reinforcing, intuitive graphics, the EnergyGuide label conveys at a glance the relative energy efficiency of an appliance within the group of similar appliances. ${ }^{150}$ At the same time, the label in no way mandates how a manufacturer may compete.

The exact same approach can be used for addressing the adequacy of homeowner's insurance to cover a total loss. For purposes of clarity of reference, the proposal of this Article will be referred to as the "CoverageGuide" program. Here are the features of the proposal, all of which would need to be incorporated into a regulatory scheme:

(1) Label. The first feature of the CoverageGuide program would be a single page (8.5" x 11") yellow label that through simple text and an intuitive graphic, conveys to the consumer (1) the relative amount of

147 See U.S. Envtl. Prot. Agency, ENergy Star and Other Climate Protection PARTNERShIPS 2008 ANNUAL RePORT, 20-21, 26-27 (Dec. 2009); accord 133 Cong. Rec. H881-01 (Mar. 3, 1987) (comments of Rep. Joe Barton) ("Experience shows that mandatory efficiency labels have successfully encourage [sic] consumers to purchase efficient products. At the same time, labels have allowed consumers the freedom of choice."); 59 Fed. Reg. 34,014 at 34,020-33; Appliance Labeling Rule, 72 Fed. Reg. 6836, 6838-41 (Feb. 13, 2007) (discussing results of FTC's consumer research); Transcript of FTC Energy Labeling Public Workshop (May 3, 2006), available at http://www.ftc.gov/os/comments/energylabeling-workshop/060503wrkshoptrnsc ript.pdf (recording approval of appliance labeling by representatives of manufacturers Whirlpool and JVC); Robert F. Dyer \& Thomas J. Maronick, An Evaluation of Consumer Awareness and Use of Energy Labels in the Purchase of Major Appliances: A Longitudinal Study, 7 J. PUB. POL'Y \& MARKETING (SPECIAL ISSUE ON THE FTC) 83 (1988).

${ }_{148}$ See 16 C.F.R. pt. 305, promulgated pursuant to 42 U.S.C. $\S 6201$ et seq.

149 16 C.F.R. $\S 305.11(\mathrm{a})(1)$.

${ }^{150}$ See 16 C.F.R. $\S 305.11$ (a)(5)(ii)(C). 
offered coverage under the proposed policy, compared to (2) the likely amount of coverage necessary in the event of a total loss. In contrast to the EnergyGuide label, this approach would add one additional, minor level of complexity: the amount of money the consumer would have to pay for the insurance at various levels. The text, of course, would be mandated, both in terms of content, font, emphasis, and placement. ${ }^{151}$ This label is intentionally designed to look just like the EnergyGuide label. The label would look as follows:

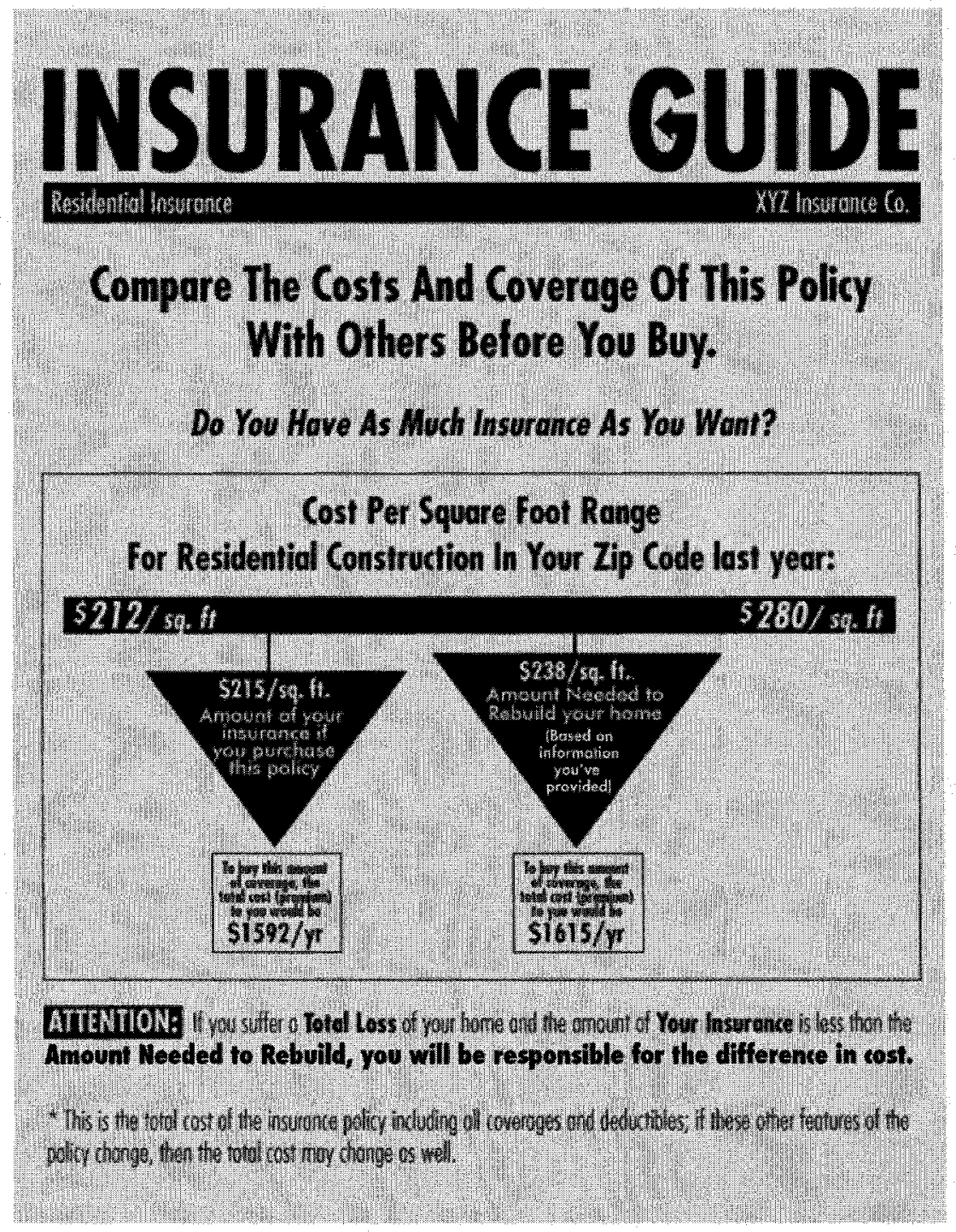

${ }^{151}$ For an example of how this is achieved in a regulation, see 16 C.F.R. $\S$ 305.11(a), which does precisely this for the EnergyGuide label. 
One of the key elements of this proposed label is that there is a shared responsibility between insurer and insured. The homeowner bears responsibility and risk in three ways. First, the homeowner is informed that the amount of insurance the homeowner actually needs to rebuild in the event of total loss is calculated "based on information you've provided." Second, the homeowner is warned: "ATTENTION: If you suffer a Total Loss of your home and the amount of Your Insurance is less than the Amount needed to Rebuild, you would be responsible for the difference in cost." Finally, the homeowner receives notice that if the features of the coverage and deductibles actually purchased change, then the cost of the insurance may also change.

(2) Timing. The notice to the homeowner describing the cost as dependent upon the coverage and deductibles highlights a second important feature of the proposed CoverageGuide program: timing. One dilemma when purchasing insurance is that the policyholder may not get the full copy of the policy (where, for example, the clause stating that the amount of insurance is the homeowner's responsibility may reside) until after the insurance is purchased and the initial premium is paid. The proposed CoverageGuide program would require that the yellow page "label" be the cover page of any quote for the purchase or renewal of homeowners' insurance. This requirement eliminates any discussion of whether the homeowner was adequately and timely informed of the level of coverage.

(3) Guaranteed Replacement Insurance. The third feature of the proposed CoverageGuide program is an approach to make sure the methodology for the critical calculations-the cost of rebuilding the home-provides the consumer with clear and adequate information while preserving the ability of insurers to freely and vigorously compete for customers. A homeowner's protection from loss is no better than the accuracy of the calculation of the cost to rebuild the home. Yet an insurer either may not wish to incur the cost of a comprehensive evaluation of rebuild costs, or may have a preferred method of calculation that the insurer considers to give it a competitive advantage. As Marshall \& Swift/Boeckh has comprehensively reported, however, there is not unanimity in the methodology for calculating adequacy of coverage. ${ }^{152}$

This then leads to the third feature of the proposed CoverageGuide program: the insurer can use any methodology the insurer chooses; however, if there is a total loss, and if the insurer's own methodology results in inadequate insurance, then the policy shall be deemed as a matter of law to be guaranteed replacement insurance. This leaves the insurer to compete as the insurer chooses, but simultaneously protects the homeowner against the insurer getting it wrong.

${ }^{152}$ WeLLS, supra note 8 , at 18-59. 
(4) Mandatory Full Coverage Option. The fourth feature of the program is a simple one: the insurer must provide at least one coverage option that provides full coverage in the amount calculated by the insurer as the actual cost to rebuild the home after a total loss. The homeowner may not want this level of coverage, but by providing the option, the insurer is insulated from the after-the-fact assertion that the homeowner had no opportunity to fully insure the home for a total loss.

(5) Binding Features. The fifth feature of the program is intended to insulate the homeowner from clauses in the full insurance policy that undercut the CoverageGuide "label." The problem with the clause in the Everett insurance policy was that the clause simultaneously put the risk of inadequate insurance on the homeowner and gave the homeowner incentive to not focus on the adequacy of coverage. Similar mischief can be avoided under the CoverageGuide program by prohibiting the content of the insurance policy to alter the first four features of the programmost importantly, the fourth feature outlined immediately above.

(6) Presumption of Adequate Information. The final feature of the program bars the homeowner from suing the insurer under the assertion that the homeowner unintentionally had coverage that was inadequate in amount. This is the converse of deeming the insurer as providing full replacement coverage (the third feature). Here, if the insurer fully and completely complies with all of the first five features of the program, then the homeowner shall be deemed, as a matter of law, to have been adequately informed of the amount of coverage.

\section{THE CASE FOR THE PROPOSAL}

On its face, this program seeks to eliminate or at least reduce the frequency of both identified inefficiencies in the homeowner insurance market. Dispute costs will be reduced since litigation will be explicitly banned. Information inadequacy will be reduced because of the clarity of the disclosures.

Additionally, the program is designed to preserve competition. An insurer essentially can do anything it wishes in setting price. Thus, the program satisfies the goal of disclosing information more effectively without unnecessarily impairing the ability of competitors to compete.

An EnergyGuide-like label for insurance has a variety of advantages. First, unlike most approaches to remedying information imbalances in consumer commercial information, there is data demonstrating that this approach works. While legislatures and courts have explored any number of other approaches-ranging from strict liability law to product labeling to the doctrine of caveat emptor-virtually no data support the effectiveness of any other approach. 
By mimicking the visual look of the EnergyGuide label, consumers see a familiar form, which they immediately understand as providing important information in a comparative format. ${ }^{153}$ The EnergyGuide label is ubiquitous. Thus, even at a glance consumers recognize the yellow label as conveying important information comparing potential product choices. Utilizing this same aesthetic approach in insurance transactions provides sufficient assurance that the purchaser either knew or should have known about the adequacy of the insurance, making a bar to litigation appropriate.

In turn, insurers are given something of immediate value-an approach that insulates them from litigation. Put another way, a legislator or regulator in the arena of insurance would recognize two public policy gains: (1) the policy maker could have comfort in concluding that, in the event of inadequate insurance to rebuild, the homeowner was in a bed of their own making; and (2) at least in the particular context of the cost of adequate homeowner's insurance, the policy maker would be insulated from the argument of insurers, when seeking to raise rates, that the cost of frivolous litigation was the primary driver.

The concern of insurance companies-the ability to compete on the basis of price-also survives this regulatory approach. Insurance companies can price insurance and even calculate rebuilding costs however they wish. If a company wishes to bear some backend risk in order to garner immediate market share, then that is completely acceptable.

The combination of three factors - some risk shifting to the insured, the bar on some kinds of litigation, and the protection of the insurer to compete, price, and rate how the insurer chooses-should lessen industry resistance to the proposal.

Finally, the proposed CoverageGuide "label" scores "fairly easy" to understand under the Flesch Readability index.

\section{THe CASE AGAINST THE PRoposal (AND A RESPONSE TO IT)}

A prominent criticism of this proposal certainly will come from insurers, who will assert that it fails to understand the nature of their business. This criticism takes several forms, including that the proposal does not recognize how an insurer needs to seamlessly renew policies ${ }^{154}$

U.S. Envtl. Prot. Agency, energy Star and Other Climate PROTECTION PARTNERShIPS 2008 ANNUAL REPORT, at 20-21, 26-27 (Dec. 2009).

${ }^{154}$ Given that residential property insurance is placed as part of the purchase of a house, and the premium frequently is built into the monthly mortgage payment, 
(in other words, not spend insurer time and customer time annually reevaluating value and coverage); and the proposal does not recognize how hard, nuanced, uncertain, and expensive it can be for an insurer to properly value a home.

These factors are, however, accounted for in this proposal. The proposal first reflects a choice between two approaches: leaving the valuation methodology up to the insurer, or imposing a methodology on all insurers by regulatory fiat. The proposal rejects the fiat for two reasons. First, a fiat strips insurers of one way in which they can differentiate and compete with each other. Second, a fiat imposes an untested model that might or might not be accurate. What the proposal finds unacceptable is giving the insurer leeway to invest as much or as little attention into valuation as the insurer wishes, but then allowing the insurer to shift the risk of undervaluation to the homeowner. The insurer, in order to remain in business, has to engage in some evaluation of the risk it writes or indemnifies. The insurer should not be allowed to internally undertake that evaluation, and nonetheless externally shift the risk of error to its customer. ${ }^{155}$ Thus, the proposal seeks to balance interests between the insurer and insured by (1) giving the insurer both the freedom to write and value risk as it wishes and a litigation shield from insureds who purchase less coverage than actually necessary, but (2) giving insureds protection through policy reformation should the disclosed valuation be, in retrospect, inaccurate. ${ }^{156}$ Further, the insurer's responsibility for undervaluation is tempered by the basing the valuation on information provided by the homeowner.

Unspoken but inherent in industry criticism of the proposal will be another concern: the CoverageGuide label sets a price or floor in claimsadjusting negotiations. Put another way, clear and unambiguous rebuild cost data cuts the legs out of a potential profit strategy of the insurer -adjusting claims at below the actual per-square-foot price of

one would expect a material part of the business of residential property insurance to be achieving high renewal persistency.

${ }^{155}$ Insurers sometimes assert that the homeowner is best positioned to know the value of the home. This may be an oblique reference to asymmetry of information concerns that animate adverse selection. But insurers already have to underwrite risk in the face of this asymmetry, and most profitably do so without having an Everett-like firewall clause.

${ }^{156}$ A potential problem arises in instances of mass loss, because scarcity can distort per-square-foot construction costs. This can be dealt with, however, with the sorts of riders now written, which give a percentage increase in coveragetypically $25 \%$ or $50 \%$ if actual rebuild costs exceed caps. This "extended" coverage, as it is called, is designed to address precisely these kinds of scenarios. The "reformation" prong of the proposal is intended to calculate rebuild costs in a non-scarcity market. 
rebuilding. ${ }^{157}$ This is undoubtedly true. But it is a strength of the proposal, not a weakness, if it truncates an unfair claims-handling practice (intentionally offering a low settlement in recognition that many insureds will undervalue their claim because of information imbalance and emotional vulnerability in the immediate wake of loss).

A related criticism will be that this proposal fails to understand the nature of homeowners purchasing insurance. This may take the form of saying that homeowners will pay attention no more to this disclosure than any other, and that insurance is moving away from paper transactions. As to the latter concern, the disclosure can just as easily be the first screen ${ }^{158}$ of an e-commerce transaction as it can be the first page of a paper transaction. As to the former concern, it is simply unacceptable to bind insurers to a future of inevitable "inadequate disclosure" litigation no matter how plain the disclosure; at some level of disclosure the homeowner must take personal responsibility for the homeowner's choices.

Another potential criticism of this proposal is that it is too specific. According to this criticism, it is impossible to write the perfect contract, and fixing one informational inadequacy in a complex contract transaction is at best an incremental gain. But the rebuilding of a home is, for most individuals, the single largest and most complex financial transaction of their lives, ${ }^{159}$ and as discussed above, total loss claims account for a disproportionate share of any actual losses from underinsurance. If there is any single aspect of consumer insurance that merits attention in isolation, then one could make a good case for it being the total loss coverage provided in homeowners' insurance.

This proposal is incomplete for residents of areas that suffer a type of total loss that insurance may or may not respond to (i.e. residents who lost their homes to Hurricane Katrina in New Orleans), as the disclosure form does not clarify the precise boundaries of coverage. To respond to these critics: the more one tries to put on the form, the less effective it

157 For an extended, albeit non-neutral, discussion of the various incentives insurers have to use the claims adjusting process as a profit opportunity, see JAY M. Feinman, Delay Deny Defend: Why Insurance Companies Don't Pay Claims and What You Can Do About It (2010).

158 In light of the proliferation of, and variation in, ecommerce, a good regulation will need to pay special attention to defining what is the "first screen."

${ }^{159}$ The only transaction which might rival rebuilding of a home would be the original purchase of the same home. Because real estate as a general matter (and over any time line of length) appreciates, and because new construction is both more expensive and more complex than the purchase of an existing home, the purchase of a home still is a smaller and materially less complex transaction. 
will be in conveying anything at all. Further, if one tried to use the "Yellow label" approach for all aspects of consumer insurance, the repetition of the solution would swallow up its efficacy. There will be a breaking point somewhere, and insurance contracts long ago surpassed the threshold of too much content to be assimilated by the ordinary consumer.

Regulation, of course, is not the proper response to every single problem. It is cogent to argue that mandatory rules regulating risk in consumer contracts are necessary only when sellers' "incentives are flawed by some market failure, ${ }^{\prime 160}$ but that is precisely the case here.

A concern with a proposal, such as this one, highlighting a particular risk is that it minimizes the importance of all other risks. ${ }^{161}$ But this is the single largest, and most consequential risk. Put another way, the cost of not addressing this risk-leaving matters as they are-is too great. Highlighting multiple risks would mimic the way insurance works right now, attempting to convey so much that nothing is actually conveyed.

It might be argued that this proposal is politically impossible to achieve. Insurers are famously resistant even to rational change. ${ }^{162}$ Campaign contributions do matter to elections, ${ }^{163}$ and insurers are legendary campaign contributors. ${ }^{164}$ Consumer advocates undoubtedly will argue that the insurance industry cannot be trusted to not carve up or co-opt this proposal in the lawmaking process, thus changing it from one of balance to one that hurts consumers. Free-floating fear of making a bad situation worse, however, is not a basis to not try to make a bad situation better. Offering insurers a litigation shield without impairing an insurer's ability to compete should ameliorate much potential opposition.

One might argue that there is a simpler solution: a single regulation straightforwardly mandating that all coverage be "guaranteed replacement coverage." That most assuredly would work. But equally assuredly, the industry would resist it fiercely, and likely ultimately defeat it. After all, that was the market as it existed before 1994, which the industry now has almost wholly abandoned as a business model.

Similarly, simply tightening current regulations to require insurance contracts in their entirety to score "easy" on the Flesch readability index

\footnotetext{
${ }^{160}$ Craswell, supra note 132 , at 363.

${ }^{161}$ Schwarcz, supra note 15, at 1433-34.

162 Michelle E. Boardman, Contra Proferentem: The Allure of Ambiguous Boilerplate, $104 \mathrm{MICH}$. L. REV. 1105, 1106 (2006).

${ }^{163}$ Jeffrey N. Sheff, The Myth of the Level Playing Field: Knowledge, Affect and Repetition in Public Debate, 75 Mo. L. REv. 143, 150-57 (2010).

${ }^{164}$ Insurance: Long-Term Contribution Trends, OPENSECRETS.ORG, http://www. opensecrets.org/industries/indus.php?ind=F09 (last visited Apr. 1, 2011).
} 
would not work. A document of that length and complexity is incapable of getting such a score on Flesch-indeed, that is precisely the problem.

Finally, and to an economist most damning, is the possibility that requiring full insurance to be offered will increase the incidence of home losses as a result of moral hazard. While this is a theoretical concern, it demonstrably is a de minimus one. Here is why: According to census data, in an average year, there are 30,000 total loss homes. Many of these are lost in mass disasters, which obviously cannot be a loss due to moral hazard, and many others are lost to non-insurable causes, such as flood. So there are perhaps 20,000 total loss homes a year that might even theoretically be homes lost because of moral hazard. Moral hazard arises only to insured homes. Only $80 \%$ of homes are insured at all, so that gets the set down to 16,000 . Moral hazard concerns primarily arise if homes are fully insured. Only roughly half of insured homes are fully insured. That gets the set down to 8000 homes that could be a moral hazard loss.

As discussed earlier, there are reasons to question whether moral hazard really accounts for any lost homes at all. For argument's sake, assume some figure that you believe is actually too high, like $10 \%$. Assume that $10 \%$ of those 8000 homes would not have been lost but for risks taken due to moral hazard. Now apply that to 2007, the year that had the most losses of homes to disaster loss of any recent year of record. In 2007, the average value of homes was $\$ 191,500$. If moral hazard causes the annual loss of 800 homes of an average value of roughly $\$ 200,000$, and which absent moral hazard would not have been lost, then moral hazard causes insurers to experience an incurred loss annually of $\$ 160,000,000$. But, of course, insurers are in the actuary business, and so they do not incur this loss, but rather pass it through in premium.

So what is the "cost" of moral hazard, assuming it actually occurs in residential insurance markets? In 2006, the National Association of Insurance Commissioners calculated the average residential property insurance premium as $\$ 801$, across sixty million policies. ${ }^{165}$ If $\$ 160,000,000$ is spread across $60,000,000$ policies costing an average premium of $\$ 801$ each per year, moral hazard apparently would increase this premium by about $\$ 2.67$ per policy per year, or put another way, a premium increase of roughly one-third of one percent. In summary, while "moral hazard" is a frequent (and sometimes legitimate) concern in evaluating proposals to more effectively spread risk, here it is so demonstrably de minimus that it should not factor into an analysis.

${ }^{165} 2006$ Dwelling Fire, Homeowners Owner-Occupied, and Homeowners Tenant and Condominium/Cooperative Unit Owner's Insurance Report, NAIC, 34 tbl.4, http://www.naic.org/documents/research_stats_homeowners_sa mple.pdf. 


\section{CONCLUSION}

While it may initially seem odd to treat the purchase of home insurance the same as buying a washer dryer, it is an acceptable solution to address information inadequacy in the insurance markets. The current market structure promotes inefficiencies that are entirely avoidable, and morally dubious. Put another way, the current marketplace is not structured in a way where we would expect consensus that underinsured homeowners like Ms. Everett brought financial ruin on themselves. An approach that eliminates inefficiencies, preserves free competition, and provides confidence that homeowners know what they are buying should be embraced. 


\section{APPENDIX A}

California: ${ }^{166}$

5. Property Insurance. Borrower shall keep the improvements now existing or hereafter erected on the Property insured against loss by fire, hazards included within the term "extended coverage," and any other hazards including, but not limited to, earthquakes and floods, for which Lender requires insurance. This insurance shall be maintained in the amounts (including deductible levels) and for the periods that Lender requires. What Lender requires pursuant to the preceding sentences can change during the term of the Loan. The insurance carrier providing the insurance shall be chosen by Borrower subject to Lender's right to disapprove Borrower's choice, which right shall not be exercised unreasonably. Lender may require Borrower to pay, in connection with this Loan, either: (a) a one-time charge for flood zone determination, certification and tracking services; or (b) a one-time charge for flood zone determination and certification services and subsequent charges each time remappings or similar changes occur which reasonably might affect such determination or certification. Borrower shall also be responsible for the payment of any fees imposed by the Federal Emergency Management Agency in connection with the review of any flood zone determination resulting from an objection by Borrower.

If Borrower fails to maintain any of the coverages described above, Lender may obtain insurance coverage, at Lender's option and Borrower's expense. Lender is under no obligation to purchase any particular type or amount of coverage. Therefore, such coverage shall cover Lender, but might or might not protect Borrower, Borrower's equity in the Property, or the contents of the Property, against any risk, hazard or liability and might provide greater or lesser coverage than was previously in effect. Borrower acknowledges that the cost of the insurance coverage so obtained might significantly exceed the cost of insurance that Borrower could have obtained. Any amounts disbursed by Lender under this Section 5 shall become additional debt of Borrower secured by this Security Instrument. These amounts shall bear interest at the Note rate from the date of disbursement and shall be payable, with such interest, upon notice from Lender to Borrower requesting payment.

All insurance policies required by Lender and renewals of such policies shall be subject to Lender's right to disapprove such policies, shall include a standard mortgage clause, and shall name Lender as mortgagee and/or as an additional loss payee and Borrower further

${ }^{166}$ California Security Instrument Form 3005: Word, EFANNIEMAE.COM, https://www.efanniemae.com/sf/formsdocs/documents/secinstruments/doc/3005 w.doc. 
agrees to generally assign rights to insurance proceeds to the holder of the Note up to the amount of the outstanding loan balance. Lender shall have the right to hold the policies and renewal certificates. If Lender requires, Borrower shall promptly give to Lender all receipts of paid premiums and renewal notices. If Borrower obtains any form of insurance coverage, not otherwise required by Lender, for damage to, or destruction of, the Property, such policy shall include a standard mortgage clause and shall name Lender as mortgagee and/or as an additional loss payee and Borrower further agrees to generally assign rights to insurance proceeds to the holder of the Note up to the amount of the outstanding loan balance.

In the event of loss, Borrower shall give prompt notice to the insurance carrier and Lender. Lender may make proof of loss if not made promptly by Borrower. Unless Lender and Borrower otherwise agree in writing, any insurance proceeds, whether or not the underlying insurance was required by Lender, shall be applied to restoration or repair of the Property, if the restoration or repair is economically feasible and Lender's security is not lessened. During such repair and restoration period, Lender shall have the right to hold such insurance proceeds until Lender has had an opportunity to inspect such Property to ensure the work has been completed to Lender's satisfaction, provided that such inspection shall be undertaken promptly. Lender may disburse proceeds for the repairs and restoration in a single payment or in a series of progress payments as the work is completed. Unless an agreement is made in writing or Applicable Law requires interest to be paid on such insurance proceeds, Lender shall not be required to pay Borrower any interest or earnings on such proceeds. Fees for public adjusters, or other third parties, retained by Borrower shall not be paid out of the insurance proceeds and shall be the sole obligation of Borrower. If the restoration or repair is not economically feasible or Lender's security would be lessened, the insurance proceeds shall be applied to the sums secured by this Security Instrument, whether or not then due, with the excess, if any, paid to Borrower. Such insurance proceeds shall be applied in the order provided for in Section 2.

If Borrower abandons the Property, Lender may file, negotiate and settle any available insurance claim and related matters. If Borrower does not respond within 30 days to a notice from Lender that the insurance carrier has offered to settle a claim, then Lender may negotiate and settle the claim. The 30-day period will begin when the notice is given. In either event, or if Lender acquires the Property under Section 22 or otherwise, Borrower hereby assigns to Lender (a) Borrower's rights to any insurance proceeds in an amount not to exceed the amounts unpaid under the Note or this Security Instrument, and (b) any other of Borrower's rights (other than the right to any refund of unearned premiums paid by Borrower) under all insurance policies covering the 
Property, insofar as such rights are applicable to the coverage of the Property. Lender may use the insurance proceeds either to repair or restore the Property or to pay amounts unpaid under the Note or this Security Instrument, whether or not then due.

New York: ${ }^{167}$

5. Borrower's Obligation to Maintain Hazard Insurance or Property Insurance. I will obtain hazard or property insurance to cover all buildings and other improvements that now are, or in the future will be, located on the Property. The insurance will cover loss or damage caused by fire, hazards normally covered by "Extended Coverage" hazard insurance policies, and any other hazards for which Lender requires coverage, including, but not limited to earthquakes and floods. The insurance will be in the amounts (including, but not limited to, deductible levels) and for the periods of time required by Lender. What Lender requires under the last sentence can change during the term of the Loan. I may choose the insurance company, but my choice is subject to Lender's right to disapprove. Lender may not disapprove my choice unless the disapproval is reasonable. Lender may require me to pay either (a) a one-time charge for flood zone determination, certification and tracking services, or (b) a one-time charge for flood zone determination and certification services and subsequent charges each time remappings or similar changes occur which reasonably might affect the flood zone determination or certification. If I disagree with the flood zone determination, I may request the Federal Emergency Management Agency to review the flood zone determination and I promise to pay any fees charged by the Federal Emergency Management Agency for its review.

If I fail to maintain any of the insurance coverages described above, Lender may obtain insurance coverage, at Lender's option and my expense. Lender is under no obligation to purchase any particular type or amount of coverage. Therefore, such coverage will cover Lender, but might or might not protect me, my equity in the Property, or the contents of the Property, against any risk, hazard or liability and might provide greater or lesser coverage than was previously in effect. I acknowledge that the cost of the insurance coverage so obtained might significantly exceed the cost of insurance that I could have obtained. Any amounts disbursed by Lender under this Section 5 will become my additional debt secured by this Security Instrument. These amounts will bear interest at the interest rate set forth in the Note from the date of disbursement and will be payable with such interest, upon notice from Lender to me requesting payment.

${ }^{167}$ New York Security Instrument Form 3033: Word, EFANNIEMAE.COM, https:// www.efanniemae.com/sf/formsdocs/documents/secinstruments/doc/3033w.doc. 
All of the insurance policies and renewals of those policies will include what is known as a "Standard Mortgage Clause" to protect Lender and will name Lender as mortgagee and/or as an additional loss payee. The form of all policies and renewals will be acceptable to Lender. Lender will have the right to hold the policies and renewal certificates. If Lender requires, I will promptly give Lender all receipts of paid premiums and renewal notices that I receive.

If I obtain any form of insurance coverage, not otherwise required by Lender, for damage to, or destruction of, the Property, such policy will include a Standard Mortgage Clause and will name Lender as mortgagee and/or as an additional loss payee.

If there is a loss or damage to the Property, I will promptly notify the insurance company and Lender. If I do not promptly prove to the insurance company that the loss or damage occurred, then Lender may do so.

The amount paid by the insurance company for loss or damage to the Property is called "Insurance Proceeds." Unless Lender and I otherwise agree in writing, any Insurance Proceeds, whether or not the underlying insurance was required by Lender, will be used to repair or to restore the damaged Property unless: (a) it is not economically feasible to make the repairs or restoration; (b) the use of the Insurance Proceeds for that purpose would lessen the protection given to Lender by this Security Instrument; or (c) Lender and I have agreed in writing not to use the Insurance Proceeds for that purpose. During the period that any repairs or restorations are being made, Lender may hold any Insurance Proceeds until it has had an opportunity to inspect the Property to verify that the repair work has been completed to Lender's satisfaction. However, this inspection will be done promptly. Lender may make payments for the repairs and restorations in a single payment or in a series of progress payments as the work is completed. Unless Lender and I agree otherwise in writing or unless Applicable Law requires otherwise, Lender is not required to pay me any interest or earnings on the Insurance Proceeds. I will pay for any public adjusters or other third parties that I hire, and their fees will not be paid out of the Insurance Proceeds. If the repair or restoration is not economically feasible or if it would lessen Lender's protection under this Security Instrument, then the Insurance Proceeds will be used to reduce the amount that I owe to Lender under this Security Instrument. Such Insurance Proceeds will be applied in the order provided for in Section 2. If any of the Insurance Proceeds remain after the amount that I owe to Lender has been paid in full, the remaining Insurance Proceeds will be paid to me.

If I abandon the Property, Lender may file, negotiate and settle any available insurance claim and related matters. If I do not answer, within 
30 days, a notice from Lender stating that the insurance company has offered to settle a claim, Lender may negotiate and settle the claim. The 30-day period will begin when the notice is given. In either event, or if Lender acquires the Property under Section 22 of this Security Instrument or otherwise, I give Lender my rights to any Insurance Proceeds in an amount not greater than the amounts unpaid under the Note and this Security Instrument. I also give Lender any other of my rights (other than the right to any refund of unearned premiums that I paid) under all insurance policies covering the Property, if the rights are applicable to the coverage of the Property. Lender may use the Insurance Proceeds either to repair or restore the Property or to pay amounts unpaid under the Note or this Security Instrument, whether or not then due. 


\section{APPENDIX B}

\section{iinc.}

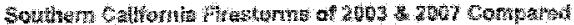

\begin{tabular}{|c|c|c|c|c|c|c|c|}
\hline Vater & $\begin{array}{l}\text { Acras } \\
\text { Bumad }\end{array}$ & 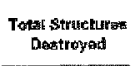 & $\begin{array}{l}\text { Totel Hones } \\
\text { Destroyed }\end{array}$ & Insilfod LOESAS & $\begin{array}{l}\text { Total } \\
\text { clatms }\end{array}$ & $\begin{array}{l}\text { Total Requert } \\
\text { for } \\
\text { Assistance }\end{array}$ & 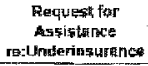 \\
\hline $\begin{array}{l}2003 \\
2007\end{array}$ & $\begin{array}{l}7 \pm 9,597 \\
518,021\end{array}$ & $\begin{array}{l}4,856 \\
3,167\end{array}$ & $\begin{array}{l}3,631 \\
2,700\end{array}$ & $\begin{array}{c}\text { \$2.2.2 billion } \\
\text { us to } \$ 2.36 \text { billiamix }\end{array}$ & $\begin{array}{r}14,100 \\
35,000\end{array}$ & $\begin{array}{l}870 \\
455 !\end{array}$ & $\begin{array}{l}316 \\
7931\end{array}$ \\
\hline \multicolumn{8}{|c|}{ 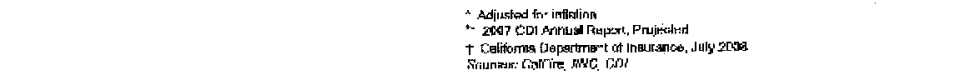 } \\
\hline
\end{tabular}




\section{APPENDIX C}

18) LIQUIDATED DAMAGES: By placing their initials immediately below, Buyer and Seller agree that it would be impracticable or extremely difficult to fix actual damages in the event of a default by Buyer, that the amount of Buyer's Deposit hereunder (as same may be increased by the terms hereof) is the parties' reasonable estimate of Seller's damages in the event of Buyer's default, and that upon Buyer's default in its purchase obligations under this agreement, not caused by any breach by Seller, Seller shall be released from its obligations to sell the Property and shall retain Buyer's Deposit (as same may be increased by the terms hereof) as liquidated damages, which shall be Seller's sole and exclusive remedy in law or at equity for Buyer's default.

Buyer's Initials Seller's Initials

31) ARBITRATION OF DISPUTES: If a controversy arises with respect to the subject matter of this Purchase Agreement or the transaction contemplated herein (including but not limited to the parties' rights to the Deposit or the payment of commissions as provided herein), Buyer, Seller and Agent agree that such controversy shall be settled by final, binding arbitration in accordance with the Commercial Arbitration Rules of the American Arbitration Association, and judgment upon the award rendered by the arbitrator(s) may be entered in any court having jurisdiction thereof.

NOTICE: BY INITIALING IN THE SPACE BELOW YOU ARE AGREEING TO HAVE ANY DISPUTE ARISING OUT OF THE MATTERS INCLUDED IN THE "ARBITRATION OF DISPUTES" PROVISION DECIDED BY NEUTRAL ARBITRATION AS PROVIDED BY CALIFORNIA LAW AND YOU ARE GIVING UP ANY RIGHTS YOU MIGHT POSSESS TO HAVE THE DISPUTE LITIGATED IN COURT OR JURY TRIAL. BY INITIALING IN THE SPACE BELOW YOU ARE GIVING UP YOUR JUDICIAL RIGHTS TO DISCOVERY AND APPEAL, UNLESS SUCH RIGHTS ARE SPECIFICALLY INCLUDED IN THE "ARBITRATION OF DISPUTES" PROVISION. IF YOU REFUSE TO SUBMIT TO ARBITRATION AFTER AGREEING TO THIS PROVISION, YOU MAY BE COMPELLED TO ARBITRATE UNDER THE AUTHORITY OF THE CALIFORNIA CODE OF CIVIL PROCEDURE. YOUR AGREEMENT TO THIS ARBITRATION PROVISION IS VOLUNTARY.

WE HAVE READ AND UNDERSTAND THE FOREGOING AND AGREE TO SUBMIT DISPUTES ARISING OUT OF THE MATTERS INCLUDED IN THE "ARBITRATION OF DISPUTES" PROVISION TO NEUTRAL ARBITRATION.

Buyer's Initials Seller's Initials

Buyer's Agent's Initials Seller's Agent's Initials 